\title{
Unexpected discovery of six new species of Aphyosemion (Cyprinodontiformes, Aplocheilidae) in the Wonga-Wongué Presidential Reserve in Gabon
}

\author{
Jean-François AGNESEE ${ }^{1, *}$, Laurent CHIRIO ${ }^{2}$, Olivier LEGROS ${ }^{3}$, \\ Richard OSLISLY ${ }^{4} \&$ Hervé Mvé BHÉ ${ }^{5}$ \\ ${ }^{1}$ ISEM, CNRS, Univ. Montpellier, IRD, EPHE, Montpellier, France. \\ ${ }^{2} 14$, rue des Roses, 06130 Grasse, France. \\ ${ }^{3}$ Floralaan 51, 1501 Buizingen, Belgium. \\ ${ }^{4}$ Patrimoines Locaux et Gouvernance UMR 208, IRD, MNHN, Paris, France. \\ ${ }^{4}$ Agence Nationale des Parcs Nationaux (ANPN), BP 20379, Libreville, Gabon. \\ ${ }^{5}$ Institut de Recherches Agronomiques et Forestières (IRAF), Centre National de la Recherche \\ Scientifique et Technologique (CENAREST), BP 2246, Libreville, Gabon. \\ *Corresponding author: jean-francois.agnese@ird.fr \\ 2Email:1chirio@hotmail.com \\ ${ }^{3}$ Email: olivier.legros@belgacom.net \\ [4Email: richard.oslisly@ird.fr \\ 5Email:woleuntem@hotmail.com

\footnotetext{
${ }^{1}$ urn:1sid:zoobank.org:author:8AEF0368-6444-4E50-8C72-23CCC65E69A5

${ }^{2}$ urn:1sid:zoobank.org:author:33A241AD-4C70-4A0A-8E30-B137E4FC771F

${ }^{3}$ urn:1sid:zoobank.org:author:F13EB21F-A391-451B-8139-9AA0F90AEF52

${ }^{4}$ urn:lsid:zoobank.org:author:1DC16C89-E5DB-43F2-874D-AAB2DC8BAF50

${ }^{5}$ urn:1sid:zoobank.org:author:2F0F18BD-C1AF-401B-94FE-0CB0AD1A8DE5
}

\begin{abstract}
During a survey of the fishes in the region of the Wonga-Wongué Presidential Reserve, 14 new populations of the subgenus Chromaphyosemion Myers, 1924 were found. These observations extend the previously known distribution range of the subgenus 120 kilometres southward. None of these populations could be related to any described species. Based on the colouration of the males and females, together with a genetic marker (mitochondrial DNA cytochrome $b$ sequences), the populations studied are grouped into six new species which are described in this article, all close to Aphyosemion alpha Huber, 1998 with which they share the presence of a black alpha-shaped mark on the pre- and post-opercular region. The group composed of $A$. alpha and the six new species is referred to here as the $A$. alpha species group. All the new species, A. aurantiacum Chirio, Legros \& Agnèse sp. nov., A. barakoniense Chirio, Legros \& Agnèse sp. nov., A. flammulatum Chirio, Legros \& Agnèse sp. nov., A. flavocyaneum Chirio, Legros \& Agnèse sp. nov., A. pusillum Chirio, Legros \& Agnèse sp. nov. and A. rubrogaster Chirio, Legros \& Agnèse sp. nov., are further unambiguously diagnosed by unique combinations of colour patterns, making it possible to generate an identification key for the A. alpha species group. It is likely that the coastal dunes of Wonga-Wongue that form a sandy relief, could have
\end{abstract}


led to the fragmentation and then isolation of the hydrographical networks that flow into the Atlantic Ocean, making possible a significant number of allopatric speciations.

Keywords. Killifish, mtDNA, Nothobranchiidae, taxonomy.

Agnèse J.-F., Chirio L., Legros O., Oslisly R. \& Mvé Bhé H. 2018. Unexpected discovery of six new species of Aphyosemion (Cyprinodontiformes, Aplocheilidae) in the Wonga-Wongué Presidential Reserve in Gabon. European Journal of Taxonomy 471: 1-28. https://doi.org/10.5852/ejt.2018.471

\section{Introduction}

Fishes of the genus Aphyosemion Myers, 1924 inhabit small rivers and freshwater streams in tropical and equatorial Africa, from Togo to Angola (Huber 2006). The genus is composed of more than 90 species. Since there is a considerable overlapping in meristic characters among species of Aphyosemion (Huber 2000; Scheel 1968, 1990; Wildekamp 1993), diagnoses generally rely on the extraordinary colour patterns of males. Scheel $(1968,1990)$ combined information from colour patterns, karyotypes, hybridization experiments and distribution to discern sets of related species, which he called species groups. Scheel (1990) recognized nine species groups, named after their emblematic species, A. batesii (Boulenger, 1911), A. bivittatum (Lönnberg, 1895), A. calliurum (Boulenger, 1911), A. cameronense (Boulenger, 1903), A. coeleste Huber \& Radda, 1977, A. elegans (Boulenger, 1899), A. exiguum (Boulenger, 1911), A. georgiae Lambert \& Géry, 1968 and A. striatum (Boulenger, 1911), but admitted that certain species were difficult to place definitively into any one of these groups. Species from the A. bivittatum group (Scheel 1968) can easily be distinguished from all the other species of Aphyosemion through several characters, including the presence of two dark lateral bands in both sexes (vs one or none) and the ability of males to change their colouration rapidly depending on stress or their hierarchical status (vs less conspicuous changes in other Aphyosemion). The A. bivittatum group is now placed in Chromaphyosemion Radda, 1971 which is considered as a subgenus of Aphyosemion (Agnèse et al. 2006; Collier 2006) or a full genus (Legros et al. 2005; Sonnenberg 2000, 2007a, 2007b; Völker 2006). Agnèse et al. (2006) and Collier (2006) demonstrated that Chromaphyosemion is a monophyletic group, but still considered it as a subgenus of Aphyosemion until a complete taxonomic revision of the genus is done. The subgenus Chromaphyosemion is distributed from Togo to Gabon (Huber 2006), north of the equator, but most of its diversity (12 of 19 valid species) is found in Cameroon.

Until the present study, a population of A. alpha from Gabon, in the Owendo area south of Libreville $(0.30750 \mathrm{~N}$ and $9.50972 \mathrm{E})$, was the southernmost population known. During our survey of fishes from south of Libreville, with emphasis on the region of the Wonga-Wongue Presidential Reserve, we found new populations of Chromaphyosemion all the way from Libreville to Owendo, and then south to the equator, from $0.04404 \mathrm{~S}$ to $0.70581 \mathrm{~S}$.

Obviously, some of them are not conspecific with any described species. Within Chromaphyosemion it is not always easy to distinguish species, because there are no meristic differences between them. Species are only distinguished by male colouration and sometimes female colour patterns as well. Recently, the use of genetic markers (mitochondrial DNA sequences) has been very useful for solving many of the questions about the taxonomic status of certain populations (Agnèse et al. 2006, 2013; Sonnenberg 2007a, 2007b). Morphological, phenotypical and genetic analyses were performed in order to evaluate the taxonomic status of these newly-discovered populations in the coastal plains of Gabon.

\section{Material and methods}

\section{Fish samples}

Samples were collected in Gabon (fishing and export permit numbers AE0004/14/MESRS/CENAREST/ CG/CST/CSAR and AE0006/16/MESRS/ CENAREST/CG/CST/CSAR) using dipnets, between April 


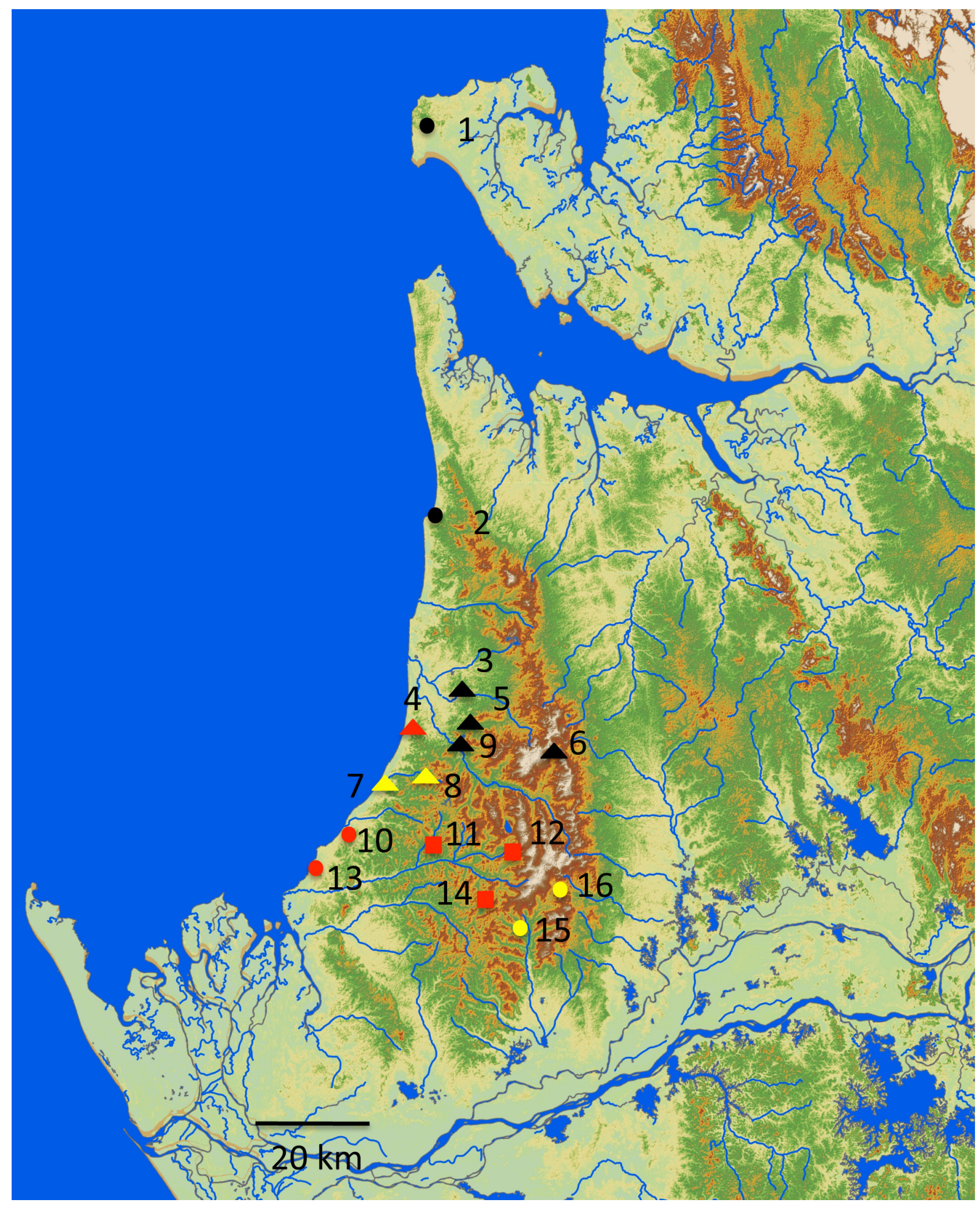

Fig. 1. Collecting sites of the different populations. Black circles: Aphyosemion alpha Huber, 1998; Black triangles: A. flavocyaneum Chirio, Legros \& Agnèse sp. nov.; red triangle: A. flammulatum Chirio, Legros \& Agnèse sp. nov.; yellow triangles: A. barakoniense Chirio, Legros \& Agnèse sp. nov.; red circles: A. pusillum Chirio, Legros \& Agnèse sp. nov.; yellow circles: A. rubrogaster Chirio, Legros \& Agnèse sp. nov.; red squares: A. aurantiacum Chirio, Legros \& Agnèse sp. nov. 
Table 1. Species identification; population number $\left(\mathrm{N}^{\circ}\right)$ on the map (Fig. 1) and on the phylogenetic network (Fig. 2); voucher specimen references registered at the Royal Museum for Central Africa (MRAC), Tervuren (Belgium); coordinates.

\begin{tabular}{ccccc}
\hline Species name & $\mathbf{N}^{\circ}$ & $\begin{array}{c}\text { Voucher MRAC } \\
\text { specimen 2016-019-P }\end{array}$ & \multicolumn{2}{c}{ Coordinates } \\
\hline \multirow{3}{*}{ A. flavocyaneum } & 6 & $1-10$ & $0.42874 \mathrm{~S}$ & $9.54502 \mathrm{E}$ \\
& 9 & & $0.43460 \mathrm{~S}$ & $9.38216 \mathrm{E}$ \\
& 5 & & $0.38381 \mathrm{~S}$ & $9.39902 \mathrm{E}$ \\
A flammulatum & 3 & & $0.32762 \mathrm{~S}$ & $9.39489 \mathrm{E}$ \\
\hline \multirow{2}{*}{ A. barakoniense } & 7 & $11-18$ & $0.39594 \mathrm{~S}$ & $9.30772 \mathrm{E}$ \\
\hline \multirow{2}{*}{ A. pusillum } & 8 & $19-36$ & $0.47664 \mathrm{~S}$ & $9.26483 \mathrm{E}$ \\
& 10 & $37-56$ & $0.45815 \mathrm{~S}$ & $9.33465 \mathrm{E}$ \\
\hline \multirow{2}{*}{ A. aurantiacum } & 13 & $57-59$ & $0.55590 \mathrm{~S}$ & $9.21322 \mathrm{E}$ \\
& 11 & $60-63$ & $0.61282 \mathrm{~S}$ & $9.15650 \mathrm{E}$ \\
\hline \multirow{2}{*}{ A. rubrogaster } & 14 & $64-73$ & $0.58186 \mathrm{~S}$ & $9.46718 \mathrm{E}$ \\
A. alpha & 16 & $74-91$ & $0.56336 \mathrm{~S}$ & $9.33732 \mathrm{E}$ \\
& 15 & 92 & $0.66401 \mathrm{~S}$ & $9.42652 \mathrm{E}$ \\
\hline
\end{tabular}

2014 and March 2016, from 16 natural populations, of which 14 (3 to 16) were from the WongaWongué Presidential Reserve. The fish were anaesthetized with phenoxyethanol and then preserved in $90 \%$ alcohol. Collection localities and taxonomic identification of the samples are shown in Fig. 1 and Table 1.

\section{Morphometric and phenotypic studies}

Descriptions are based on wild-caught specimens registered in the collection of the Royal Museum of Central Africa (MRAC) in Tervuren, Belgium (Table 1). Phenotypic studies, diagnoses, descriptions and the identification key were made using $\mathrm{Xper}^{2}$ (Ung et al. 2010). Morphometric data were obtained as described in Huber (2000) using a stereo microscope. Measurements were made with a digital calliper, corrected to the nearest $0.1 \mathrm{~mm}$. All ratios are expressed as percentages of standard length (SL). Colouration data and live specimen photographs were obtained from wild fish after a few weeks to a few months in captivity. No colour variation was observed between individuals in the same population as is usually the case with this group of species.

\section{Genetic study}

Total genomic DNA was extracted from fin tissues (voucher specimens were deposited at the ISE-M, Montpellier, reference numbers are listed in Table 1) using the protocol described in Sambrook et al. (1989). A fragment of the mitochondrial gene cytochrome $b$ was sequenced and used to both reconstruct a mitochondrial gene tree and evaluate genetic divergence. PCR was performed with two specific primers (ctb-F1 5'AACCACCGTTGTTATTCAAC3' forward and ctb-R1 $5^{\prime}$ CTCCCAAAGCCAGAATTCTAAA3' reverse). The amplification protocol consisted of 3 min at $93^{\circ} \mathrm{C}$ for initial denaturation, followed by 30 cycles of $30 \mathrm{sec}$ at $93^{\circ} \mathrm{C}, 30 \mathrm{sec}$ at $53^{\circ} \mathrm{C}$ for annealing, $1 \mathrm{~min} 30 \mathrm{sec}$ at $72^{\circ} \mathrm{C}$ for extension, and a final 5 min extension step at $72^{\circ} \mathrm{C}$. 
AGNÈSE J.-F. et al., Six new species of Aphyosemion (Cyprinodontiformes, Aplocheilidae)

Table 2. GenBank accession numbers, species identification, voucher specimen references registered at the Institut des Sciences de l'Évolution de Montpellier (ISEM).

\begin{tabular}{ccc}
\hline GenBank numbers & Species name & Voucher reference \\
\hline MG779236 & & ISEM-LCH-108 \\
MG779237 & & ISEM-LCH-138 \\
MG779238 & A. flavocyaneum & ISEM-LCH-171 \\
MG779239 & & ISEM-LCH-107 \\
MG779240 & ISEM-LCH-141 \\
MG779241 & ISEM-LCH-139 \\
MG779242 & & ISEM-LCH-168 \\
MG779243 & A flammulatum & ISEM-LCH-167 \\
\hline MG779244 & \multirow{2}{*}{ A. barakoniense } & ISEM-LCH-162 \\
\hline MG779245 & A. pusillum & ISEM-LCH-352 \\
MG779246 & ISEM-LCH-356 \\
MG779247 & ISEM-LCH-351 \\
\hline MG779245 & ISEM-LCH-144 \\
MG779250 & A. aurantiacum & ISEM-LCH-355 \\
MG779251 & & ISEM-LCH-143 \\
\hline MG779252 & ASEM-LCH-350 \\
\hline MG779253 & \multirow{2}{*}{ A. rubrogaster } & ISEM-LCH-169 \\
MG779254 & \multirow{2}{*}{ A. alpha } & ISEM-LCH-145 \\
\hline
\end{tabular}

\section{Phylogenetic analyses}

All sequences were edited and aligned using Seqscape version 2.5 and subsequently inspected and corrected manually (Table 2). The sequences of all the valid species, obtained in a previous work (Agnèse et al. 2013) from the subgenus Chromaphyosemion, were included in the analyses: A. alpha Huber, 1998 (GenBank reference KC893920), A. bitaeniatum (Ahl, 1924) (KC893922), A. bivittatum (Lönnberg, 1895) (KC893813), A. ecucuense (Sonnenberg, 2007) (KC893923), A. erythron (Sonnenberg, 2007) (KC893926), A. kouamense Legros, 1999 (KC893921), A. koungueense (Sonnenberg, 2007) (KC893896), A. loennbergii (Boulenger, 1903) (KC893884), A. lugens Amiet, 1991 (KC893894), A. malumbresi Legros \& Zentz, 2007 (KC893927), A. melanogaster (Legros, Zentz \& Agnèse, 2005) (KC893892), A. melinoeides (Sonnenberg, 2007) (KC893892), A. omega (Sonnenberg, 2007) (KC893882), A. pamaense Agnèse, Legros, Cazaux \& Estivals, 2013 (KC893888), A. poliaki Amiet, 1991 (KC893913), A. punctulatum (Legros, Zentz \& Agnèse, 2005) (KC893907), A. riggenbachi (Ahl, 1924) (KC893889), A. splendopleure (Brüning, 1929) (KC893904) and A. volcanum Radda \& Wildekamp, 1977 (KC893879).

Aphyosemion franzwerneri Scheel, 1971 (KC893930), A. ahli Myers, 1933 (KC893931), A. exiguum (Boulenger, 1911) (KC893928), A. elberti (Ahl, 1924) (KC893929), A. amoenum Radda \& Purzl, 1976 (KC893932) and A. cameronense (Boulenger, 1903) (KC893993) are species closely-related to Chromaphyosemion (Agnèse et al. 2006; Collier 2006) and were used as an out-group in the analysis. Tree search analyses were performed with (1) Maximum Likelihood (ML) (Stamakis 2014, RAxML, ver. 8), (2) Distance (Kimura 1980) and Neighbour Joining methods (Saitou \& Nei 1987) and (3) Minimum Evolution approaches (Nei et al. 1998; Takahashi \& Nei 2000). Supports for inferred clades were obtained through the nonparametric bootstrap (Felsenstein 1985), 2000 replicates for the three methods. 


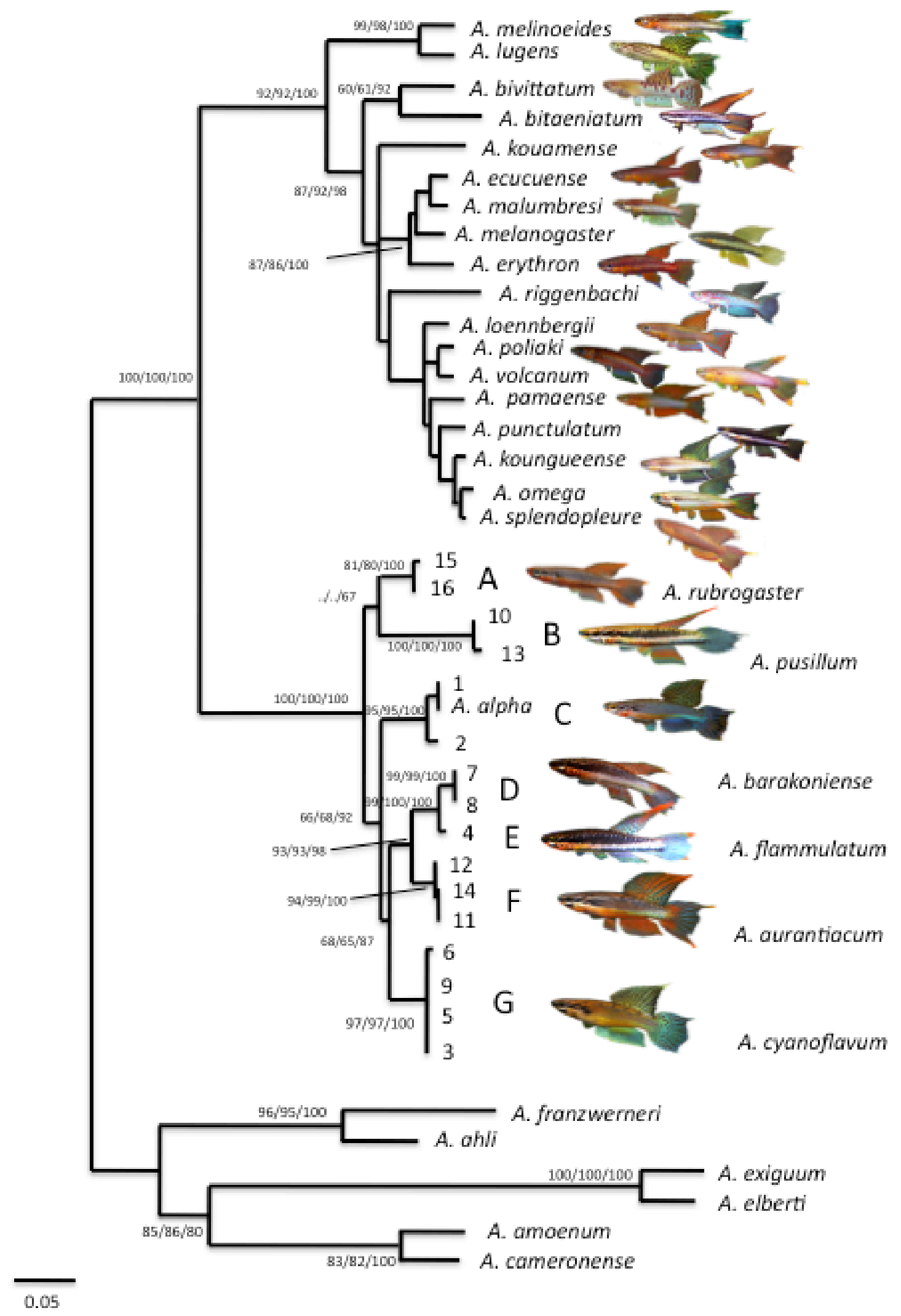

Fig. 2. Consensus tree based on Maximum Likelihood, Distance and Minimum Evolution. Numbers above the branches are percentages of bootstrap values based on 2000 replicates for each method. Numbers correspond to sample location (Fig. 1 and Table 1). Scale refers to Kimura 2 distance. 
An evolutionary model for nucleotide substitution was chosen with MEGA 5 (Tamura et al. 2011) using the Bayesian information criterion (BIC) (Schwarz 1978). The optimal model was TN93+G+I $(\mathrm{G}=1.40, \mathrm{I}=0.51)$. This model (Tamura \& Nei 1993) accounted for the difference between transitions and transversions, and differentiated the two kinds of transition. The G parameter indicates that the non-uniformity of the evolutionary rates in the sites was modelled using a discrete Gamma distribution, and the I parameter indicates that there is a proportion of invariant sites. This model was used for the subsequent ME analysis. For RAxML, data were partitioned into three matrices corresponding to the three different codon position allowing the program to choose an independent evolutionary model for each partition. The different trees were rooted using Aphyosemion franzwerneri, A. ahli, A. exiguum, A. elberti, A. amoenum and A. cameronense.

To determine the delimitation of species, we used the Bayesian program bPTP (Zhang et al. 2013) on the web-server (http://species.h-its.org/) to estimate a species tree using our maximum likelihood tree, without the root species (i.e., only using the sequences of the Chromaphyosemion subgenus).

\section{Results}

\section{Molecular analysis}

A 1028 base-pair alignment for the Cytochrome $b$ region from the mitochondrial genome was obtained after trimming the ends of each sequence. A total of 45 different sequences were obtained. A total of 456 variable sites were identified, from which 413 were parsimony informative (i.e., shared by at least two different sequences). The three different methods used, Maximum Likelihood, Distance and Minimum Evolution, gave congruent results, summarised in Fig. 2. Phylogenetic relationships within previously described species of Chromaphyosemion were congruent with the previous studies (Agnèse et al. 2006; Collier 2006).

Aphyosemion alpha and all the newly-discovered populations were grouped in a monophyletic assemblage that appeared to be the sister group of all the other species of Chromaphyosemion.

This clade, which clustered all the populations or species from Gabon except for A. kouamense, was strongly supported by high bootstrap values (99/100/100 for ML, NJ and ME respectively).

Within this clade, the populations were clearly separated into seven groups. Two of these groups (A and B) were highly supported (bootstraps from 80 to 100) and composed of populations 15 and 16 on the one hand, and 10 and 13 on the other. Both these groups clustered together and might have represented the sister group of all the other populations, but this position was not supported by high bootstrap values (89/../67). Group C (populations 1, 2 and A. alpha (populations from Cap Esterias, LEC 96-26, GenBank reference KC893920)), group D (7, 8), group E (4), group F $(11,12,14)$ and group $\mathrm{G}(3,5,6,9)$ were all supported by very high bootstrap values $(>93)$. Groups $\mathrm{D}$ and $\mathrm{E}$ both formed a monophyletic assemblage $(100 / 100 / 100)$ and, together with group F, another clade that was highly supported (98/93/98).

All the other species of Chromaphyosemion, except for A. alpha, were grouped into a monophyletic cluster that was strongly supported by high bootstrap values $(100 / 92 / 100)$. The topology of the phylogenetic tree was similar to what has been observed previously (Agnèse et al. 2013). Aphyosemion lugens and A. melinoeides occupied a basal position as the sister group of all the other species. The species from Equatorial Guinea: A. erythron, A. ecucuense, and A. malumbresi, plus A. melanogaster from Cameroon, appeared to form a monophyltic group (75/86/100).

Genetic distances (Kimura 2) observed between the haplotypes were used to create the histogram in Fig. 3. This Figure represents the distribution of distances between every pair of previously-described species, and between pairs of populations from the different groups of newly-discovered populations A 
to $\mathrm{G}$ (one population per group, here $4,8,9,13,14,16$ and A. alpha (populations from Cap Esterias)). Genetic distances among the 18 previously-described species were distributed in two (yellow) groups. On the one hand, the distances ranged from 0.013 to 0.302 , and on the other, the distances ranged from 0.412 to 0.620 . The first group corresponds to the distances between all the pairs of species, except those including $A$. alpha, and the second group corresponds to the sequences between A. alpha and all the other 18 species of Chromaphyosemion. Genetic distances (red) in the batch of newly-discovered populations, including A. alpha, ranged from 0.016 and 0.253 .

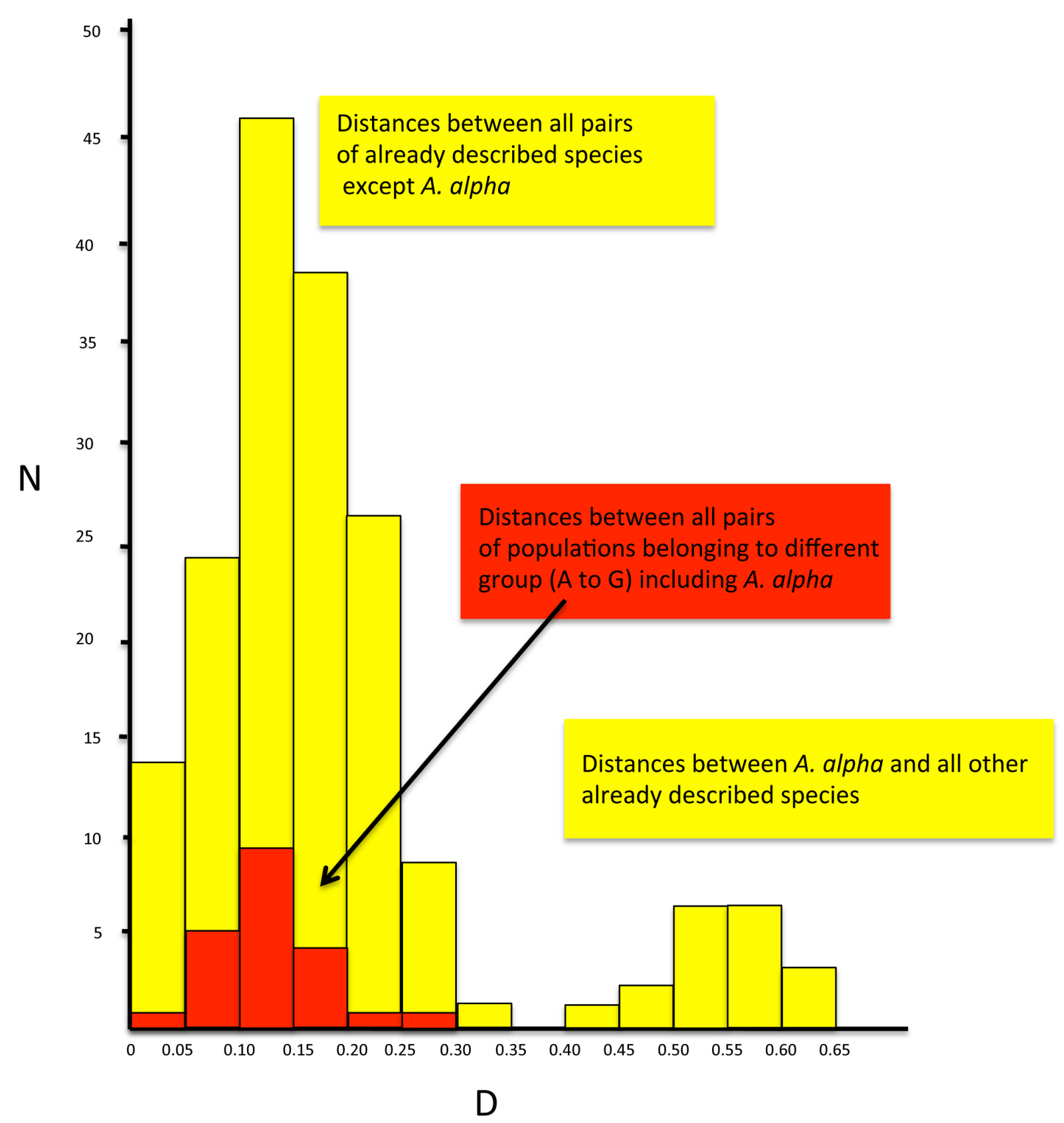

Fig. 3. Genetic distances (Kimura 2) between all pairs of species or populations. Only one population was used for group A to G, respectively population 4, 8, 9, 13, 14, 16 and Aphyosemion alpha Huber, 1998. 
Even though there is no direct relationship between genetic distance and taxonomic distance, it can be seen that genetic divergences in the different groups of newly-discovered populations (A to G) appeared to be comparable with what has been already observed at the species level in Chromaphyosemion. For example, well-recognized species such as $A$. splendopleure and $A$. omega, or A. splendopleure and A. koungueense, or $A$. koungueense and $A$. omega exhibited low genetic divergences $(0.013,0.017$, and 0.020 respectively) that were comparable to the distances observed in the present study between groups $\mathrm{D}$ and $\mathrm{E}(0.016)$.

Taking these observations into account, it is likely that all seven taxa (groups) of the southern Gabon species may represent seven different species: $A$. alpha and six others new to science. In order to verify this hypothesis, we have tried to confirm the number and the limits of the different new species present in southern Gabon using bPTP (Zhang et al. 2013). The most supported partition found by simple heuristic search, identified all previously described species except A. omega, A. koungueense and A. splendopleure which clustered together. For populations from southern Gabon, bPTP recognized seven species corresponding to the seven groups previously observed: group A (populations 15 and 16), group B $(10,13)$, group C (A. alpha from Cap Esterias together with populations 1 and 2), group D (7 and 8), group E (4), group F (11, 12 and 14) and group G (3, 5, 6 and 9).

Consequently, six species that are new to science are described below.

It should be noted that the authors of the new taxa are different from the authors of this paper (reference to Article 50.1 and Recommendation 50A of the International Code of Zoological Nomenclature; ICZN 1999).

\section{Species descriptions}

Order Cyprinodontiformes Berg, 1940

Suborder Aplocheiloidei Bleeker, 1859

Family Nothobranchiidae Garman 1895

Subfamily Nothobranchiinae Garman, 1895

Tribe Nothobranchiini Garman, 1895

Subtribe Aphyosemiina Huber, 2000

Genus Aphyosemion Myers, 1924

Aphyosemion flavocyaneum Chirio, Legros \& Agnèse sp. nov. urn:1sid:zoobank.org:act:1C559D3D-38A3-4322-A7CF-BEBC547D4D8D

Fig. 4A-D, Table 3

\section{Etymology}

The specific epithet refers to the main colours of this species (blue and yellow).

\section{Material examined}

Holotype

GABON: adult đ̊, $32.3 \mathrm{~mm}$ SL (43.2 mm TL), Lake Ndaminzé 0.42874 S, 9.54502 E, $115 \mathrm{~m}$ a.s.1., field reference code CHRSP1-Lac Ndaminzé, 13 Apr. 2014, Laurent Chirio leg. (MRAC 2016-019-P-1).

\section{Paratypes}

GABON: $3 \hat{\jmath} \widehat{\partial}, 6$ 우, $21.3-27.5 \mathrm{~mm}$ SL, same collection data as for holotype (MRAC 2016-019-P2-10). 


\section{Differential diagnosis}

Distinguished from other species of Chromaphyosemion by its blue anal fin with no submarginal red band (vs species with a submarginal red band present), except for $A$. poliaki, and very rare specimens of A. melanogaster and A. malumbresi. Differs from the latter species through a combination of the following features: flanks and venter yellow-orange with no red punctuation (vs flanks bronze, venter brown-orange, regular red dots; flanks yellow-green, venter yellow-green with a black zone, irregular lines of red dots; flanks bluish-white, venter bluish with a black zone, regular red dots), blue iridescent scales on the ventral region close to the caudal peduncle (vs red scales or black scales), black alpha-shaped mark on the preand post-opercular region (vs no alpha-shaped mark, only a few red macules), anal fin blue with an orange portion on the basal region with no punctuation except black dots on basal and/or posterobasal portions (vs anal fin blue-green with many red dots; yellow-green with red dots; bluish-white with red dots).

\section{Colouration of live males (Fig. 4A)}

FLANKS AND VENTER. Yellow-orange with no red punctuation, two greyish lateral stripes on ventral region close to caudal peduncle with some blue iridescent scales. Two rows of paradorsal golden scales in dorsal region from operculum to caudal peduncle with few black macules.

HEAD. Yellow-orange. Premaxilla and mandible yellow-orange with black lower lips, orange infraorbital region with black macule, orange post-orbital region with two black macules, yellow-orange pre-opercle with two black macules, yellow-orange opercle with two black macules; black macules on pre- and postopercular region reveal an alpha-shaped mark.

Fins. The dorsal fin is blue, but more orange near the insertion of the fin, and rows of black dots between rays. Anal fin blue with orange portion on basal region of fin, with no punctuation and no submarginal or marginal bands. Certain individuals may have some small black dots on basal region. Caudal fin blue with many carmine red dots and some carmine red streaks in upper and lower lobes; submarginal and marginal red bands absent. Acumens at apex of unpaired fins orange or white for dorsal fin, very short blue acumen for anal fin, and orange or white for caudal fin. Colour pattern of pelvic fins identical to anal fin with blue background and no submarginal band or marginal band. Pectoral fins translucent.

\section{Colouration of live females (Fig. 4B)}

FLANKS AND VENTER. Pale brown, four lines of red dots from opercle to caudal peduncle, two greyish lateral stripes, venter yellow-green, white on basal portion. Two rows of paradorsal golden scales in dorsal region, from operculum to caudal peduncle with red dots.

HEAD. Premaxilla brown, mandible pale orange with black lower lips, brown supraorbital region, white infraorbital region with red macule, grey postorbital region with two macules, white pre-opercle, yelloworange opercle with one red dot.

Fins. Dorsal fin yellow-green, rows of red dots between rays. Anal fin yellow-green with rows of red dots between rays. Caudal fin yellow-green, blue-green on distal portion, with rows of red dots between rays. Pelvic fins translucent with yellow-green reflection, red dots, blue reflection on edges. Pectoral fins are translucent.

\section{Colouration of ethanol-preserved males and females (Fig. 4C-D)}

FLANKS AND VENTER. Flanks of males grey-yellow with three short lines of red dots, venter grey-yellow with no red punctuation. Two rows of paradorsal red scales in brown dorsal region from operculum to caudal peduncle. Flanks of females grey-yellow, three lines of red dots from the opercle to the caudal peduncle. Two rows of paradorsal red scales in the brown dorsal region, from the operculum to the caudal peduncle. 

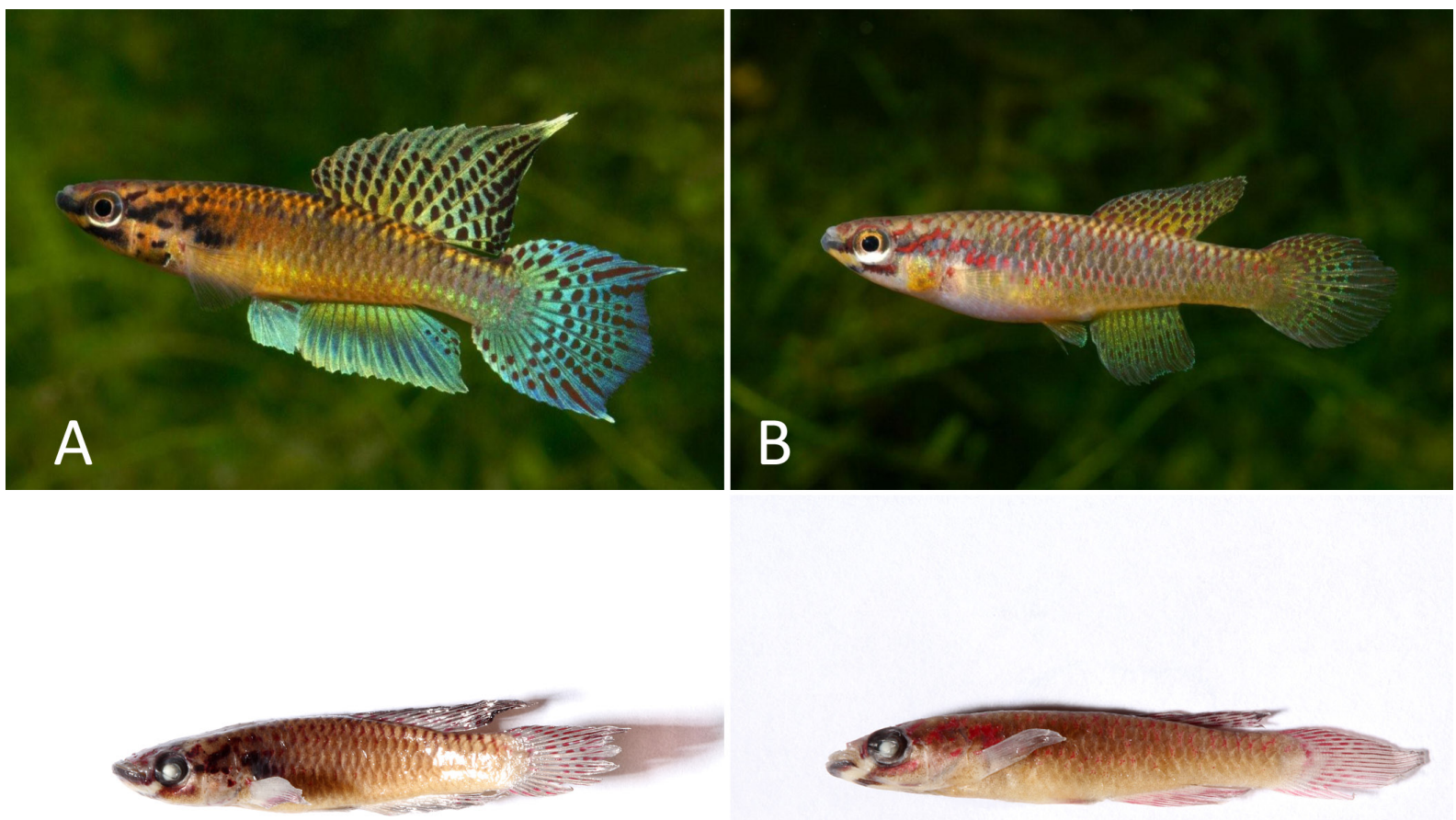

C

D
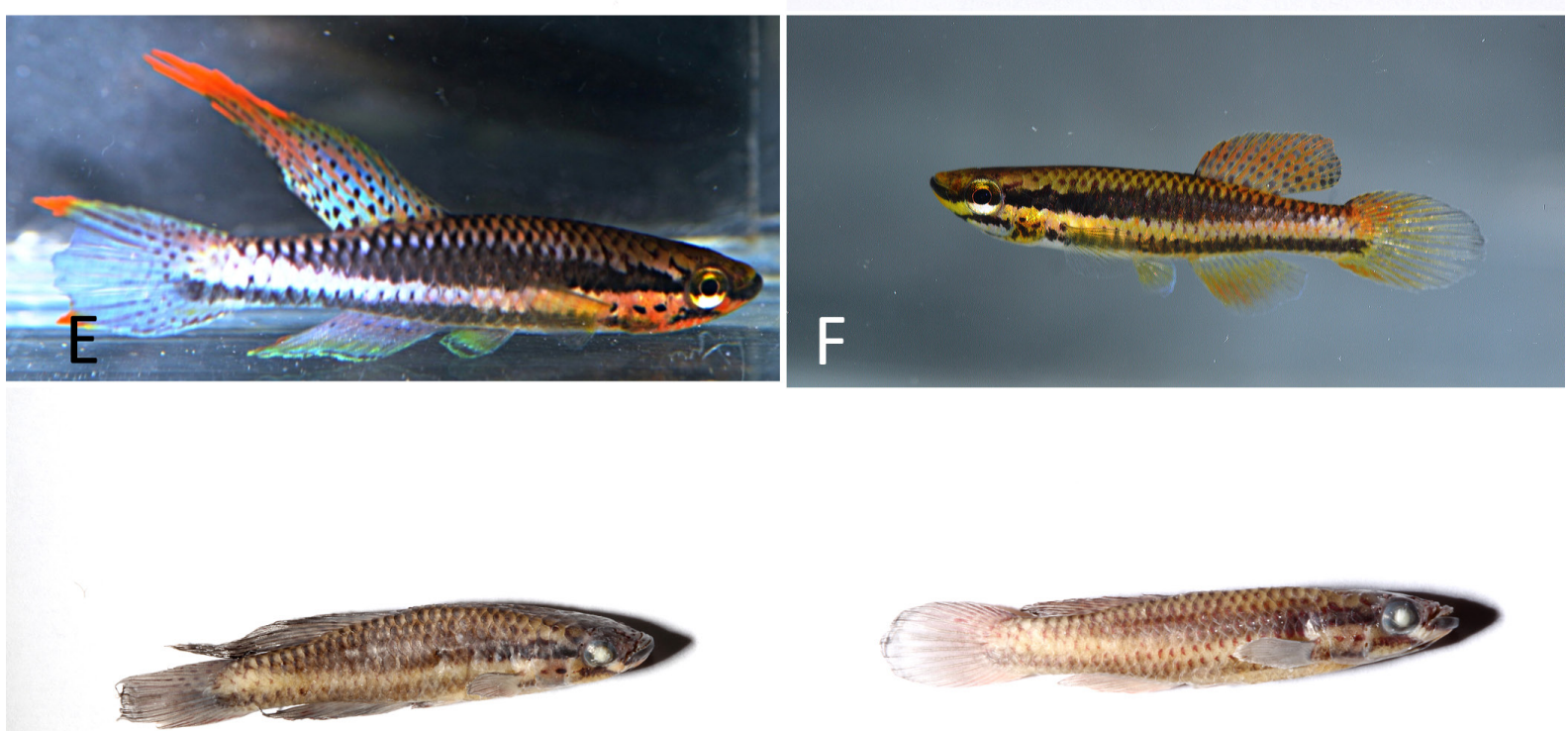

G

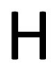

Fig. 4. A-D. Aphyosemion cyanoflavum Chirio, Legros \& Agnèse sp. nov. A. Adult, $\overbrace{}^{\Uparrow}$, from locality 9 , not preserved. Photo by O. Buisson. B. Adult, $q$, from locality 9 , not preserved. Photo by O. Buisson. C. Holotype, adult, ${ }^{\lambda}$, from Lake Ndaminzé (MRAC 2016-019-P-1). D. Paratype, adult, + , from Lake Ndaminzé (MRAC 2016-019-P-2-10). E-H. A. flammulatum Chirio, Legros \& Agnèse sp. nov. E. Adult, $\hat{\sigma}$, from locality 4, not preserved. F. Adult, + , from locality 4, not preserved. G. Holotype, adult, $\widehat{\partial}$, from the lower Aloumbé River (MRAC 2016-019-P-11). H. Paratype, adult,, , from the lower Aloumbé River (MRAC 2016-019-P-12-18). 
Table 3. Meristic and morphometric data of Aphyosemion flavocyaneum Chirio, Legros \& Agnèse sp. nov. Abbreviations: $\mathrm{A}=$ anal-fin rays; $\mathrm{D}=$ Dorsal-fin rays; $\mathrm{D} / \mathrm{A}=$ displacement of the dorsal in relation to the anal fin expressed as the number of anal fin rays; $d c p=$ caudal peduncle height; Eye = eye diameter; $\mathrm{Hd}=$ head length; $\mathrm{HT}=$ holotype values; $\mathrm{Ht}=$ height at the anal; I.O. = interorbital space; L.L. = lateral line scales, between brackets scales on the caudal fin; Max = maximum observed value; Mean $=$ mean of observed value; $\mathrm{Min}=$ minimum observed value; $\mathrm{N}=$ number of specimens studied; $\mathrm{P} . \mathrm{A} .=$ preanal distance; P.D. = predorsal distance; $\mathrm{pDor}=$ predorsal scales; P.V. preventral distance; $\mathrm{SD}=$ standard deviation; S.L. = standard length in $\mathrm{mm}$; all other measurements in percentage from S.L.; T.L. $=$ total length; TRAV $=$ transversal scales.

\begin{tabular}{ccccccc}
\hline Character & N & HT & Min & Max & Mean & SD \\
\hline D & 10 & 12 & 10 & 12 & 10.80 & 0.63 \\
A & 10 & 13 & 11 & 14 & 12.60 & 1.07 \\
D/A & 10 & -1 & -1 & 1 & 0 & 0.82 \\
L.L. & 10 & $24(+3)$ & $22(+1)$ & $26(+3)$ & $24.2(+2)$ & $1.55(+0.67)$ \\
pDor & 10 & 12 & 11 & 13 & 11.8 & 0.63 \\
TRAV & 10 & 8 & 6 & 8 & 7.1 & 0.57 \\
S.L. & 10 & 32.3 & 21.3 & 32.3 & 24.59 & 3.45 \\
T.L. (\%) & 10 & 134 & 126 & 136 & 130.87 & 4.19 \\
P.D. (\%) & 10 & 62 & 56 & 68 & 60.07 & 3.32 \\
P.A (\%) & 10 & 65 & 59 & 66 & 61.65 & 2.72 \\
P.V.(\%) & 10 & 51 & 47 & 53 & 50.05 & 1.99 \\
Ht (\%) & 10 & 22 & 17 & 22 & 18.84 & 1.33 \\
dcp (\%) & 10 & 12 & 11 & 14 & 12.23 & 0.97 \\
Hd (\%) & 10 & 31 & 30 & 36 & 32.82 & 2.32 \\
I.O. (\%) & 10 & 15 & 13 & 17 & 14.93 & 1.31 \\
Eye (\%) & 10 & 7 & 7 & 9 & 7.53 & 0.48 \\
\hline
\end{tabular}

HEAD. Premaxilla and mandible of male grey with black lower lips, infraorbital region has red macule, opercle with one red macule; very dark macules in post-opercular region. Head of female with a black lower lips, infraorbital region with a red macule. Head of female with black lower lips, infraorbital region with red macule.

Fins. Male dorsal fin grey-blue with rows of red dots between rays. Anal fin grey-blue with some small red dots in posterobasal region. Caudal fin grey-blue with many red dots and some carmine red streaks in upper and lower lobes. Female dorsal fin greyish, with rows of red dots between rays. Anal fin greyish, with rows of red dots between rays. Caudal fin greyish, with rows of red dots between rays.

\section{Distribution and habitat}

This species has been found at seven localities (for three of them, specimens have not been studied or deposited in a museum) in the Awagné River Basin (Table 1, Fig. 1), has never been found elsewhere and seems to be endemic to this hydrographic basin. It lives in small, secondary rivers and small, forest streams, often with a sandy bottom, where it can be found along the riverbanks. It hides quickly in water plants or dead leaves. In one locality, the bottom is muddy, the water quite stagnant and some fish have even been observed in small water holes. The uppermost locality is Lake Ndaminzé, which is about $1 \mathrm{~km}$ long: the species was found only under the shadow of large trees, hidden in the roots near the banks. This species was found in syntopy with an undescribed species of Aphyosemion and an undescribed species of Epiplatys. At one single locality in the Mbomba River, a tributary of the Awagné River, it was found in syntopy with Poropanchax stigmatopygus (Wildekamp \& Malumbres, 2004). 
Aphyosemion flammulatum Chirio, Legros \& Agnèse sp. nov. urn:Isid:zoobank.org:act:EEF24797-1B05-4D20-BCCB-A3336028C798

Fig. 4E-H, Table 4

\section{Etymology}

The specific epithet refers to the colour of the tip of the dorsal fin in this species (bright orange).

\section{Material examined}

\section{Holotype}

GABON: adult $\widehat{\partial}, 36.2$ mm SL (42 mm TL), lower Aloumbé River, 0.39594 S, 9.30772 E, 30 m a.s.1., field reference code CHRSP2-Aloumbé, 11 Apr. 2014, Laurent Chirio leg. (MRAC 2016-019-P-11).

\section{Paratypes}

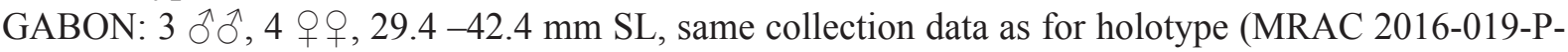
$12-18)$

\section{Differential diagnosis}

Differs from all other species in the A. alpha group through combination of following features: head intense orange, flanks purplish-blue, ventral region bluish (vs never same colour pattern), anal fin purplish-blue, with no punctuation except for some black macules in basal region and irregular submarginal red band (vs anal fin orange with or without punctuation, anal fin blue-orange with no punctuation; regular or no submarginal red band). Differs from all other species of Chromaphyosemion with black alpha-shaped mark in pre- and post-opercular region (vs no alpha-shaped mark, only a few red macules).

\section{Colouration of live males (Fig. 4E)}

FLANKS AND VENTER. Flanks purplish-blue with two very dark and often visible lateral stripes, three lines of very dark red dots from operculum to caudal peduncle. Ventral region bluish-white with some blue iridescent scales between end of anal fin and caudal peduncle. Dorsal region brown, two rows of paradorsal yellow-orange scales in dorsal region, from operculum to caudal peduncle, with two lines of carmine red dots.

HEAD. Very intense orange: premaxilla brown, mandible orange with black lower lips, brown supraorbital region, orange infraorbital region with black macule, orange pre-opercle, orange operculum with three black macules; black macules on pre- and post-opercular region reveal alpha-shaped mark.

Fins. Dorsal fin blue, orange distal portion near apex, rows of black dots between rays; very long orange acumen on apex. Anal fin purplish-blue, with no punctuation except for few black macules in basal region of fin, red, irregular submarginal band, blue marginal band, blue acumen. Caudal fin blue with orange portion in peduncle region, few red dots in basal region, very long red streaks in distal region and in upper and lower lobes, red, irregular submarginal band, blue marginal band, and acumen of very intense orange. Pelvic fins blue-orange, submarginal red band and blue marginal band. Pectoral fins with orange reflections.

\section{Colouration of live females (Fig. 4F)}

Flanks AND VENTER. Pale beige, with four lines of red and orange dots from opercle to caudal peduncle, and two very dark lateral stripes, venter yellow, white on basal portion. Two rows of paradorsal golden scales in dorsal region from operculum to start of anal fin with red dots, copper scales from start of anal fin to caudal peduncle, with red dots. 
Table 4. Meristic and morphometric data of Aphyosemion flammulatum Chirio, Legros \& Agnèse sp. nov. See Table 3 for the abbreviations used.

\begin{tabular}{ccccccc}
\hline Character & N & HT & Min & Max & Mean & SD \\
\hline D & 8 & 14 & 11 & 14 & 11.75 & 1.04 \\
A & 8 & 13 & 13 & 14 & 13.13 & 0.35 \\
D/A & 8 & 2 & 1 & 3 & 1.88 & 0.64 \\
L.L. & 8 & $25(+2)$ & $24(+1)$ & $28(+2)$ & $25.75(+1.75)$ & $1.28(+0.46)$ \\
pDor & 8 & 13 & 12 & 13 & 12.88 & 0.35 \\
TRAV & 8 & 7 & 7 & 7 & 7 & 0 \\
S.L. & 8 & 36.2 & 25.7 & 36.2 & 30.35 & 3.97 \\
T.L. (\%) & 8 & 116 & 114 & 125 & 119.37 & 3.59 \\
P.D. (\%) & 8 & 53 & 52 & 59 & 55.14 & 2.14 \\
P.A (\%) & 8 & 53 & 51 & 64 & 56.33 & 3.84 \\
P.V.(\%) & 8 & 41 & 41 & 50 & 45.4 & 2.56 \\
Ht (\%) & 8 & 20 & 16 & 26 & 19.31 & 3.2 \\
dcp (\%) & 8 & 12 & 8 & 18 & 11.68 & 2.65 \\
Hd (\%) & 8 & 30 & 10 & 30 & 25.59 & 6.22 \\
I.O. (\%) & 8 & 13 & 12 & 15 & 13.58 & 0.75 \\
Eye (\%) & 8 & 7 & 5 & 7 & 5.84 & 0.38 \\
\hline
\end{tabular}

HEAD. Premaxilla brown, mandible yellow with black lower lips, brown supraorbital region, white infraorbital region with black macule, orange postorbital region with two red macules, orange preopercle, and orange opercle with five red dots.

Fins. Dorsal fin orange, rows of carmine red dots between rays. Anal fin orange in median portion, some red dots between the rays in posteromedian portion. Caudal fin orange near caudal peduncle, yelloworange with red dots in median portion, and translucent in distal portion. Pelvic fins translucent with orange reflection, blue reflection on edges. Pectoral fins translucent with orange reflection.

Colouration of ethanol-preserved males and females (Fig. 4G-H)

FLANKS AND VENTER. Flanks of males yellowish with no red dots, upper grey visible upper lateral stripe, venter yellowish. Two rows of paradorsal black scales in brown dorsal region from operculum to caudal peduncle. Flanks of females yellowish, four lines of red dots from opercle to caudal peduncle. Two rows of paradorsal black scales in yellowish dorsal region from operculum to the caudal peduncle.

HEAD. Head of male with black lower lips, infraorbital region with black macule, dark macules in postopercular region. Head of female with black lower lips, infraorbital region with red macule, and postopercular region with dark macules.

Fins. Male dorsal fin grey with rows of red dots between rays. Anal fin grey with no dots. Caudal fin grey with red dots in median portion and some carmine red streaks in upper and lower lobes. Female dorsal fin blue-orange with red dots. Anal fin blue-orange, caudal fin blue-orange in upper and lower regions, some red dots near peduncle region.

\section{Distribution and habitat}

This species has been found at only three localities (for two of them, specimens have not been studied or deposited in a museum) in the Aloumbé Basin or from a small, unnamed river just north of the Aloumbé 
River (Table 1, Fig. 1) and never elsewhere. It also seems to be endemic to this very small, littoral hydrographic basin. It lives in very small forest streams (less than 1 metre wide), with sandy or rocky bottoms. It hides among roots or dead leaves. This species was found in syntopy with an undescribed species of Aphyosemion.

Aphyosemion barakoniense Chirio, Legros \& Agnèse sp. nov. urn:1sid:zoobank.org:act:93CAFA79-3B4F-4F39-8430-D9A0DB9A58C5

Fig. 5A-D, Table 5

\section{Etymology}

The specific epithet refers to the river in which the species was found.

\section{Material examined}

Holotype

GABON: adult đ, 39.9 mm SL (48.9 mm TL), lower Barakonié River, 0.47664 S, 9.26483 E, 5 m a.s.1., field reference code CHRSP3-Basse Barakonié, 2 Mar. 2016, Laurent Chirio leg. (MRAC 2016-019-P-19).

\section{Paratypes}

GABON: $7 \lesssim \precsim, 10$ 웅, 21.5-46.6 mm SL, same data as for holotype (MRAC 2016-019-P-20-36);

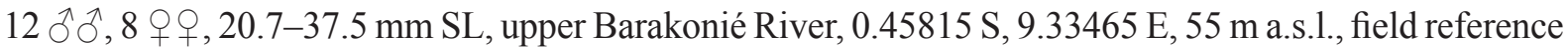
code CHRSP3-Haute Barakonié, 3 Mar. 2016, Laurent Chirio leg. (MRAC 2016-019-P-37-56).

\section{Differential diagnosis}

Differs from all other species in A. alpha group through combination of following features: head orange, flanks grey-mauve, ventral region orange (vs never same colour pattern), anal fin orange with some red dots (vs no punctuation or only black dots on posterobasal portion for A. flavocyaneum Chirio, Legros \& Agnèse sp. nov. and A. flammulatum Chirio, Legros \& Agnèse sp. nov.). Distinguished from all other species of Chromaphyosemion by alpha-shaped mark in pre- and post-opercular region (vs no alphashaped mark, only some red macules).

\section{Colouration of live males (Fig. 5A)}

FLANKS AND VENTER. Flanks grey-mauve with two dark lateral stripes, three lines of very dark red dots from opercle to caudal peduncle. Ventral region orange with some blue iridescent scales between end of anal fin and caudal peduncle. Dorsal region brown, two rows of paradorsal copper scales in dorsal region from operculum to caudal peduncle with two lines of carmine red dots.

HeAD. Orange, premaxilla brown, mandible orange with black lower lips, with brown supraorbital region, orange infraorbital region with black macule, postorbital region orange with two black macules, orange pre-opercle with two black macules, orange opercle with three black macules; black macules on pre- and post-opercular regions reveal alpha-shaped drawings.

Fins. Dorsal fin blue on basal portion, orange on upper portion, yellowish on edge of fin, with rows of carmine red dots between rays, orange acumen on apex. Anal fin mauve on basal portion, orange on median portion, yellowish portion near the submarginal band, with some carmine red macules, regular, red submarginal band, blue marginal band, small orange acumen.Caudal fin light mauve, with tips of upper and lower lobes orange, red dots on median region, short red streaks in distal region and in upper and lower lobes, irregular red submarginal band, blue marginal band, orange acumens. Pelvic fins orange with no punctuation, submarginal red band, blue marginal band. Pectoral fins with orange reflections. 


\section{Colouration of live females (Fig. 5B)}

FLANKS AND VENTER. Flanks beige-pink, four lines of red dots from opercle to caudal peduncle, two greyish lateral stripes, venter yellow, white on basal portion. Two rows of paradorsal copper scales in dorsal region from operculum to caudal peduncle with red dots.

HeAd. Premaxilla brown, mandible yellow; orange zone on side portion with black lower lips, brown supraorbital region, white infraorbital region with black macule, orange postorbital region with two black macules, orange pre-opercle, and orange opercle with two black dots.
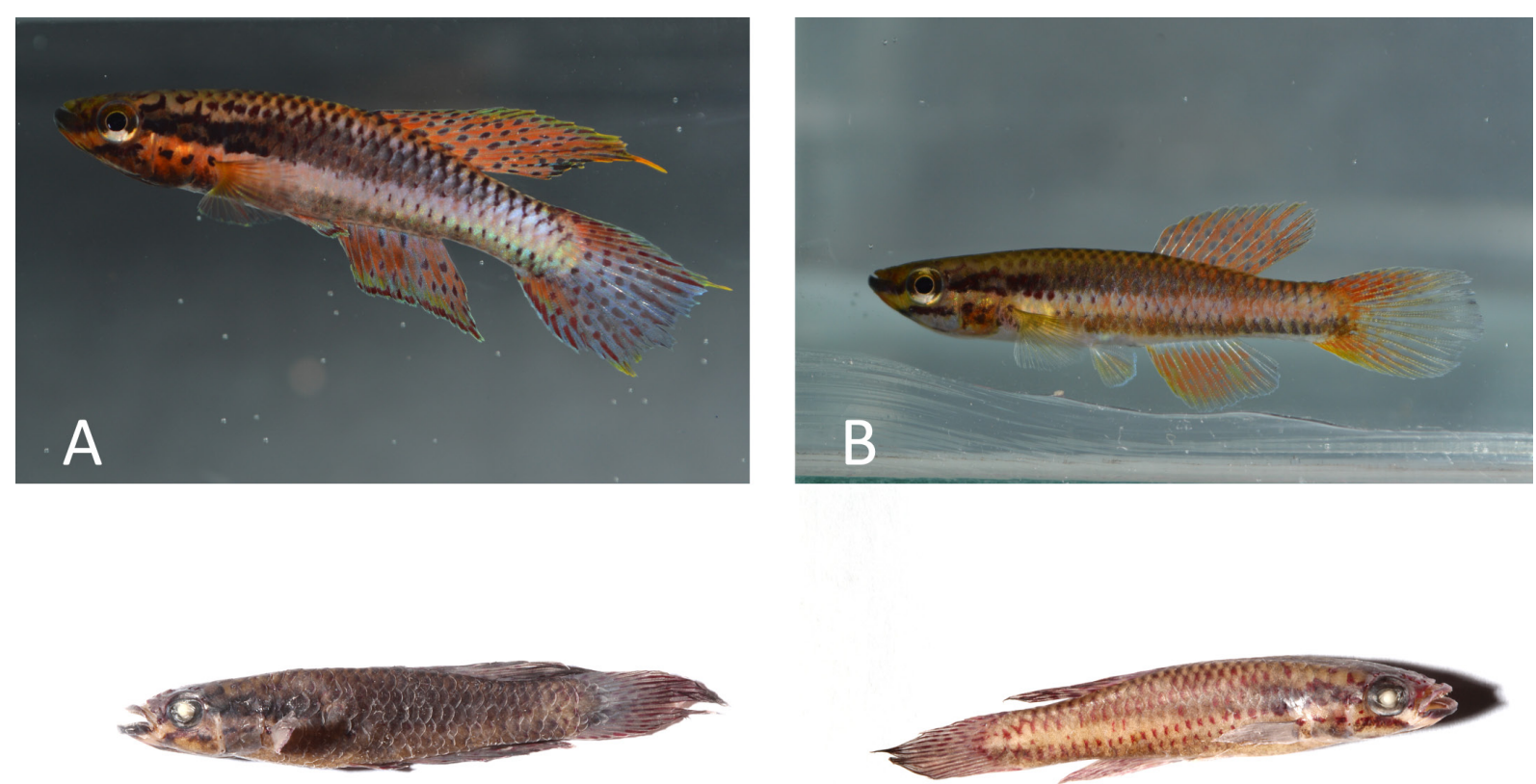

C
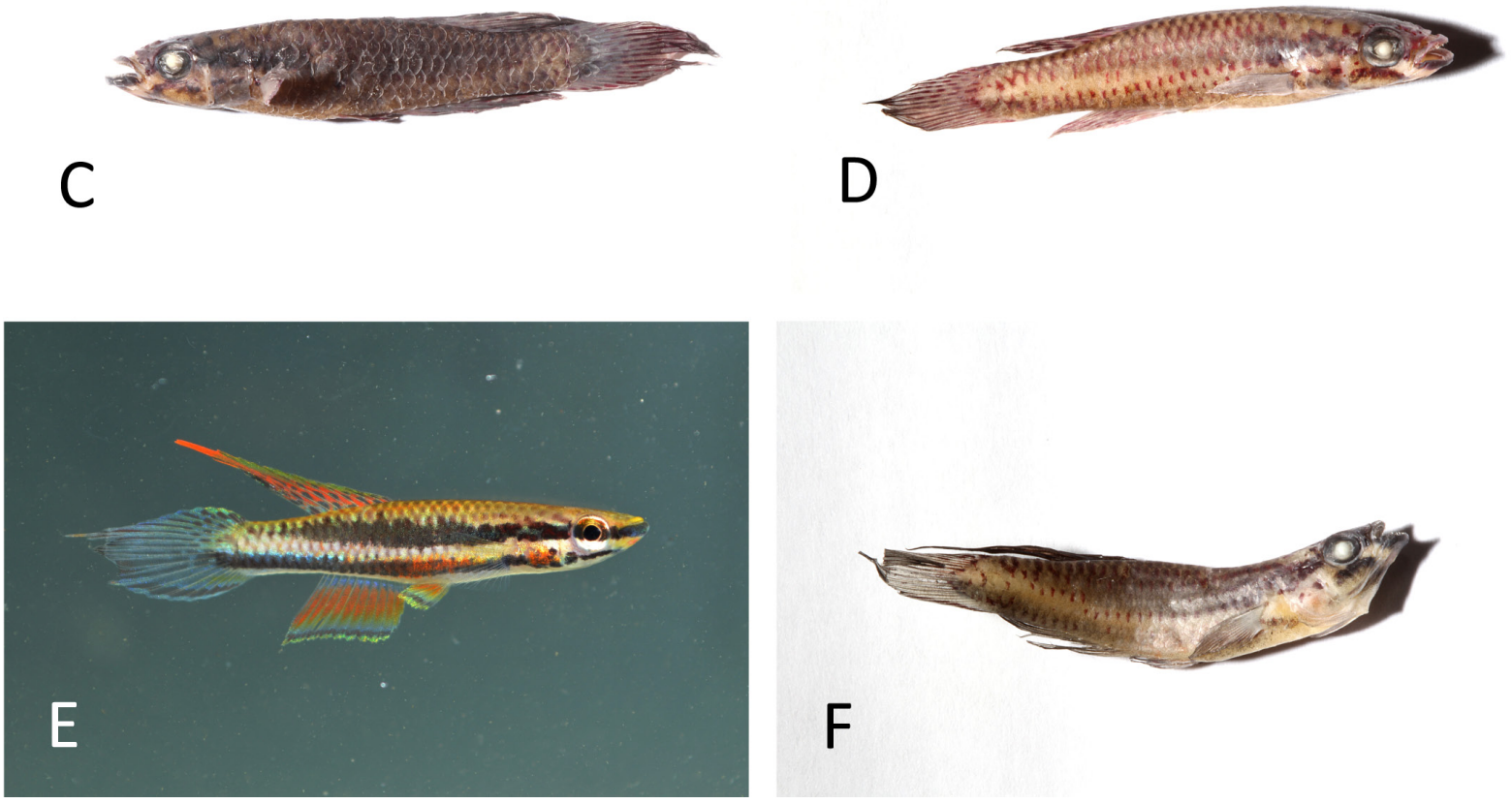

Fig. 5. A-D. Aphyosemion barakoniense Chirio, Legros \& Agnèse sp. nov. A. Adult, $\widehat{\jmath}$, from locality 7, not preserved. B. Adult, o f from locality 7, not preserved. C. Holotype, adult, $\hat{\sigma}$, from the lower Barakonié River (MRAC 2016-019-P-19). D. Paratype, adult, ㅇ, from the lower Barakonié River (MRAC 2016-019-P-20-36). E-F. A. pusillum Chirio, Legros \& Agnèse sp. nov. E. Adult, ふૈ, from locality 10, not preserved. F. Holotype, adult, $\widehat{0}$, from the Okoyo River (MRAC 2016-019-P-57). 
Table 5. Meristic and morphometric data of Aphyosemion barakoniense Chirio, Legros \& Agnèse sp. nov. See Table 3 for the abbreviations used.

\begin{tabular}{ccccccc}
\hline Character & N & HT & Min & Max & Mean & SD \\
\hline D & 38 & 11 & 10 & 14 & 11.42 & 0.83 \\
A & 38 & 13 & 11 & 15 & 12.71 & 0.96 \\
D/A & 38 & 3 & 0 & 3 & 1.37 & 1.1 \\
L.L. & 38 & $26(+2)$ & $23(+1)$ & $26(+4)$ & $24.84(+2.03)$ & $0.95(+0.49)$ \\
pDor & 38 & 13 & 11 & 14 & 12.58 & 0.68 \\
TRAV & 38 & 8 & 7 & 8 & 7.18 & 0.39 \\
S.L. & 38 & 39.9 & 20.7 & 39.9 & 28.34 & 4.91 \\
T.L. (\%) & 38 & 123 & 111 & 126 & 119.18 & 3.48 \\
P.D. (\%) & 38 & 58 & 52 & 61 & 56.91 & 2.17 \\
P.A (\%) & 38 & 57 & 49 & 60 & 55.04 & 2.8 \\
P.V.(\%) & 38 & 47 & 41 & 55 & 46.12 & 2.9 \\
Ht (\%) & 38 & 18 & 14 & 21 & 17.4 & 1.57 \\
dcp (\%) & 38 & 12 & 9 & 14 & 11.03 & 1.06 \\
Hd (\%) & 38 & 30 & 23 & 33 & 29.58 & 2.26 \\
I.O. (\%) & 38 & 12 & 10 & 15 & 12.15 & 0.97 \\
Eye (\%) & 38 & 5 & 5 & 11 & 6.43 & 1.14 \\
\hline
\end{tabular}

Fins. Dorsal fin intense orange, with rows of carmine red dots between rays. Anal fin orange on the median portion with no dots. Caudal fin intense orange near caudal peduncle, red dots between rays. Pelvic fins with orange reflection, blue reflection on edges. Pectoral fins translucent.

\section{Colouration of ethanol-preserved males and females (Fig. 5C-D)}

FLANKS AND VENTER. Flanks of males dark grey with three lines of red dots, venter grey-yellow. Two rows of paradorsal red scales in brown dorsal region from operculum to caudal peduncle. Flanks of females beige with two dark lateral stripes, six lines of red dots from opercle to caudal peduncle, venter greyyellow. Two rows of paradorsal red scales in grey dorsal region, from operculum to caudal peduncle.

Head. Premaxilla and mandible of male grey, with black lower lips, orange infraorbital region with black macule, orange pre-opercular region, orange opercle with one red macule; dark macules in postopercular region. Head of female with black lower lips, infraorbital region with red macule.

Fins. Dorsal fin of male orange with rows of red dots between rays. Anal fin orange with some small red dots, red sumarginal band. Caudal fin orange with many red dots on basal portion, red streaks on edge and in upper and lower lobes. Dorsal fin of female orange, with rows of red dots between rays. Anal fin orange, with red streaks between rays. Caudal fin orange, with rows of red dots between rays on median portion, red streaks on edge.

\section{Distribution and habitat}

This species has been found at only two localities in the Barakonié Basin (Table 1, Fig. 1) and never elsewhere. It seems to be endemic to this small, coastal hydrographic basin. In the upper Barakonié, where the river is less than $1 \mathrm{~m}$ wide, the fish live among roots or dead leaves in the middle of the river. In the lower Barakonié, where the river can be 2 to $3 \mathrm{~m}$ wide, they are not found in the main course, but only in small water holes of stagnant water close to the river, hidden among dead leaves and mud, and there, they can be very abundant. This species was found in syntopy with an undescribed species of Aphyosemion. 
Aphyosemion pusillum Chirio, Legros \& Agnèse sp. nov. urn:lsid:zoobank.org:act:529ADFCC-1E00-4715-A157-1281E749DE48

Fig. 5E-F, Table 6

\section{Etymology}

The specific epithet refers to the small size of this species.

\section{Material examined}

\section{Holotype}

GABON: adult $\hat{\jmath}, 28.5 \mathrm{~mm}$ SL (33.8 mm TL), bridge on Okoyo River, $0.55590 \mathrm{~S}, 9.21322 \mathrm{E}, 10 \mathrm{~m}$ a.s.l., field reference code CHRSP4-Okoyo, 1 Mar. 2016, Laurent Chirio leg. (MRAC 2016-019-P-57).

\section{Paratypes}

GABON: 2 ठิ, 24.5-24.8 mm SL, same collection data as for holotype (MRAC 2016-019-P-58-59);

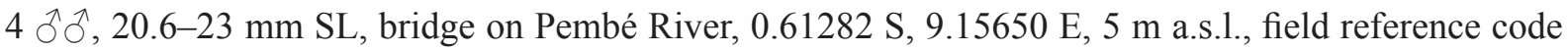
CHRSP4-Pembé, 1 Mar. 2016, Laurent Chirio leg. (MRAC 2016-019-P-60-63).

\section{Differential diagnosis}

Distinguished from all other species in A. alpha group by two delimited orange zones on body: orange portion on opercle and orange portion above pelvics fins (vs no orange portion) with beige ventral region (vs yellow-orange, white bluish or orange), anal fin orange, blue near basal portion and near submarginal red band, no punctuation (vs never a similar colour pattern). Distinguished from all other species of Chromaphyosemion by alpha-shaped mark on pre- and postopercular region, especially visible on preserved specimens (vs no alpha-shaped mark, only some red macules).

\section{Colouration of live males (Fig. 5E)}

FLANKS AND VENTER. Flanks beige with two dark lateral stripes, two lines of small red dots from opercle to caudal peduncle. Ventral region beige with some blue iridescent scales between end of anal fin and caudal peduncle, orange portion above pelvics fins. Dorsal region light brown, two rows of paradorsal copper scales from operculum to caudal peduncle with two lines of red dots.

HEAD. Beige with premaxilla brown, mandible yellow orange with black lower lips, brown supraorbital region, beige infraorbital region with black macule, postorbital region beige with one black macule, beige preopercle with one black macule, opercle yellow orange in background with orange zone with four black macules; black macules on pre- and postopercular region reveal incomplete alpha-shaped mark.

Fins. Dorsal fin orange, yellowish on edge of fin, blue on posterobasal portion of fin, rows of carmine red dots between rays, red streaks on edge of fin, orange acumen on apex. Anal fin orange, blue near basal portion of fin and near submarginal band, regular red submarginal band, yellow green marginal band, small orange acumen. No punctuation. Caudal fin blue with beginning of upper and lower lobes light orange, red dots on upper part of fin, long red streaks on upper and median regions, red regular submarginal band, blue marginal band, orange acumens. Pelvic fins orange without punctuation, blue near submarginal band, submarginal red band and yellow green marginal band. Pectoral fins translucent.

\section{Colouration of live females}

Unknown 
Table 6. Meristic and morphometric data of Aphyosemion pusillum Chirio, Legros \& Agnèse sp. nov. See Table 3 for the abbreviations used.

\begin{tabular}{ccccccc}
\hline Character & N & HT & Min & Max & Mean & SD \\
\hline D & 7 & 10 & 9 & 12 & 10.43 & 0.98 \\
A & 7 & 11 & 11 & 14 & 12.29 & 1.11 \\
D/A & 7 & 0 & 0 & 2 & 1.43 & 0.98 \\
L.L. & 7 & $27(+2)$ & $24(+2)$ & $27(+3)$ & 26.14 & $1.21(+0.49)$ \\
pDor & 7 & 13 & 13 & 15 & $13.29)$ & 0.79 \\
TRAV & 7 & 8 & 7 & 8 & 7.43 & 0.53 \\
S.L. & 7 & 28.5 & 20.6 & 28.5 & 23.59 & 2.68 \\
T.L. (\%) & 7 & 119 & 114 & 122 & 117.72 & 2.6 \\
P.D. (\%) & 7 & 56 & 56 & 61 & 58.08 & 2.52 \\
P.A (\%) & 7 & 65 & 57 & 65 & 60.48 & 2.99 \\
P.V.(\%) & 7 & 52 & 43 & 52 & 47.3 & 3.19 \\
Ht (\%) & 7 & 21 & 13 & 21 & 16.63 & 2.44 \\
dcp (\%) & 7 & 11 & 7 & 13 & 10.29 & 1.84 \\
Hd (\%) & 7 & 27 & 27 & 36 & 30.27 & 3.15 \\
I.O. (\%) & 7 & 14 & 12 & 15 & 13.91 & 1.16 \\
Eye (\%) & 7 & 6 & 6 & 9 & 7.53 & 0.99 \\
\hline
\end{tabular}

\section{Colouration of ethanol preserved males (Fig. 5F)}

FLANKS AND VENTER. Grey with three incomplete lines of red dots, venter beige with orange portion, white lower part, two grey lateral stripes. Two rows of paradorsal red scales in grey dorsal region from operculum to caudal peduncle.

HEAD. White mandible with black lower lips, white infraorbital region with black macule, white preopercular region, orange opercle; one dark macule in postopercular region.

Fins. Dorsal fin grey with rows of grey dots between rays. Anal fin with grey area on basal portion. Caudal fin grey with some red streaks on upper lobe, red dots in median portion.

\section{Colouration of preserved females}

Unknown.

\section{Distribution and habitat}

This small species has been found at only two localities in the Okoyo and Pembé Basins (Table 1, Fig. 1) and never elsewhere. The species seems to be endemic to these two small, coastal hydrographic basins, situated just north of the Wézé drainage. In the Okoyo Basin, A. pusillum Chirio, Legros \& Agnèse sp. nov. was found out of the main course of the river, in small, muddy streams less than $1 \mathrm{~m}$ wide. In the Pembé Basin, it was found directly in the course of this small river, hidden among dead leaves and water plants, in quiet places. This species was found in syntopy with an undescribed species of Aphyosemion, two undescribed species of Epiplatys and an undescribed species of Plataplochilus. 
Aphyosemion aurantiacum Chirio, Legros \& Agnèse sp. nov. urn:lsid:zoobank.org:act:93840539-567F-4817-B774-3568D388E094

Fig. 6A-D, Table 7

\section{Etymology}

The specific epithet refers to the main colour of this species (dark orange).

\section{Material examined}

\section{Holotype}

GABON: adult đ̊, $33 \mathrm{~mm}$ SL (39.7 mm TL), Wézé spring, 0.58186 S, $9.46718 \mathrm{E}, 89 \mathrm{~m}$ a.s.1., field reference code CHRSP5-sources Wézé, 3 Jul. 2014, Laurent Chirio leg. (MRAC 2016-019-P-64).

\section{Paratypes}

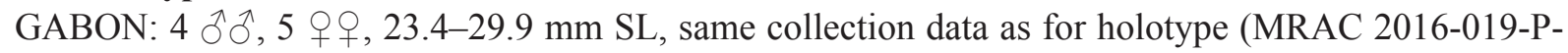

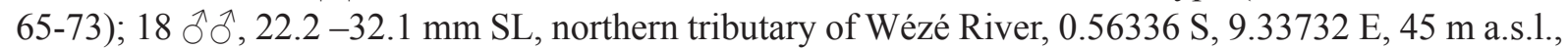
field reference code CHRSP5-Wézé2, 1 Mar. 2016, Laurent Chirio leg. (MRAC 2016-019-P-74-91); 1 , $23 \mathrm{~mm}$ SL, southern tributary of Wézé River, $0.66401 \mathrm{~S}, 9.42652 \mathrm{E}, 87 \mathrm{~m}$ a.s.l., field reference code CHRSP5-Wézé3, 5 Mar. 2016, Laurent Chirio leg. (MRAC 2016-019-P-92).

\section{Differential diagnosis}

Differs from all other species in A. alpha group through combination of following features: head orange, flanks beige, ventral region orange (vs never the same colour pattern), orange anal fin with no punctuation (vs blue-orange, purplish-blue or orange with punctuation). Distinguished from all other species of Chromaphyosemion by an alpha-shaped drawing in pre- and post-opercular region (vs no alpha-shaped drawing, only some red macules).

\section{Colouration of live males (Fig. 6A)}

FLANKS AND VENTER. Flanks beige with two grey, rarely visible lateral stripes, four lines of red dots from opercle to caudal peduncle. Ventral region orange and region between end of anal fin and caudal peduncle intense orange, two rows of blue iridescent scales between end of anal fin and caudal peduncle. Dorsal region brown, with two rows of paradorsal copper scales from operculum to caudal peduncle with two lines of carmine red dots.

HEAD. Orange with premaxilla brown, mandible orange with black lower lips, brown supraorbital region, orange infraorbital region with black macule, postorbital region orange with two black macules, orange pre-opercle with one black macule, orange opercle with two black macules; black macules on pre- and post-opercular region reveal an alpha-shaped drawing.

Fins. Dorsal fin blue, large orange zone on rays, rows of carmine red dots between rays, and carmine red streaks on distal and posterobasal portions of fin. Orange acumen on apex. Anal fin orange, blue zone near submarginal band, regular, red submarginal band, blue marginal band, orange acumen. No punctuation. Caudal fin blue with orange caudal peduncle, 5-6 red dots in median region, very long red streaks in median region and in upper and lower lobes, regular, red submarginal band, blue marginal band, and orange acumens. Pelvic fins orange with no punctuation, submarginal red band and blue marginal band. Pectoral fins with orange reflections.

\section{Colouration of live females (Fig. 6B)}

FLANKS AND VENTER. Flanks pale yellow, with four lines of red dots from opercle to caudal peduncle, two greyish lateral stripes, yellow venter, white on basal portion. Two rows of paradorsal golden scales 
in dorsal region from operculum to start of anal fin with red dots, copper scales from start of anal fin to caudal peduncle with red dots.

HEAD. Premaxilla brown, mandible pale yellow with black lower lips, brown supraorbital region, white infraorbital region with black macule, white postorbital region with two red macules, yellow pre-opercle with red dot, yellow opercle with two red dots.

Fins. Dorsal fin yellow-green, with rows of carmine red dots between rays, red streaks on distal portion. Anal fin blue on basal portion with row of red dots between rays, some red streaks between rays on median portion, pale orange on distal portion. Caudal fin yellow-green near caudal peduncle, with some red dots on basal portion, red streaks between rays from median to distal portion. Pelvic fins translucent with blue reflection on the edge. Pectoral fins translucent.

\section{Colouration of ethanol-preserved males and females (Fig. 6C-D)}

FlanKS AND VENTER. Flanks of males grey-yellow with no red dots, venter grey-yellow. Two rows of paradorsal black scales in grey-yellow dorsal region from operculum to caudal peduncle, visible greyish upper lateral stripe. Flanks of females beige with two grey lateral stripes and two lines of two to three red dots behind opercle. Venter beige, with two grey lateral stripes. Two rows of paradorsal red scales in grey dorsal region from operculum to caudal peduncle.

HEAD. Head of male grey-yellow mandible with black lower lips, grey-yellow infraorbital region with small black macule, grey-yellow pre-opercular region, opercle with two black macules; dark macules in post-opercular region. Head of female with black lower lips, infraorbital region with black macule, dark opercle.

FIns. Dorsal fin of male orange with two to three black dots on basal portion, streaks between rays on distal portion. Anal fin orange with dark rays. Caudal fin orange with many red streaks on distal portion, red submarginal band. Dorsal fin of female light orange, rows of red dots between rays. Anal fin greyish with no red dots. Caudal fin light orange, with some red dots on upper portion, red streaks on edge.

\section{Distribution and habitat}

This species has been found at three localities in the Wézé Basin (Table 1, Fig. 1) and never elsewhere. The species seems to be endemic to this hydrographic basin. It lives only in very small forest streams and water holes, often with a bottom consisting of roots and dead leaves, where it can be very abundant. In the southern-most locality, it was found hidden under dead leaves along the river banks in a 2 metre wide river with a sandy bottom. This species was found in syntopy with three undescribed species of Aphyosemion, Epiplatys and Plataplochilus.

Aphyosemion rubrogaster Chirio, Legros \& Agnèse sp. nov. urn:1sid:zoobank.org:act:1778A417-0D05-4C16-BE75-00B6DE36398C

Fig. $6 \mathrm{E}-\mathrm{H}$, Table 8

\section{Etymology}

The specific epithet refers to the colour of the ventral region of this species (red).

\section{Material examined}

Holotype

GABON: adult $\widehat{~}, 25.2 \mathrm{~mm}$ SL (31.3 mm TL), bridge on Niengé River, 0.65524 S, $9.57355 \mathrm{E}, 61 \mathrm{~m}$ a.s.1., field reference code CHRSP6-Niengué, 4 Jul. 2014, Laurent Chirio leg. (MRAC 2016-019-P-93). 

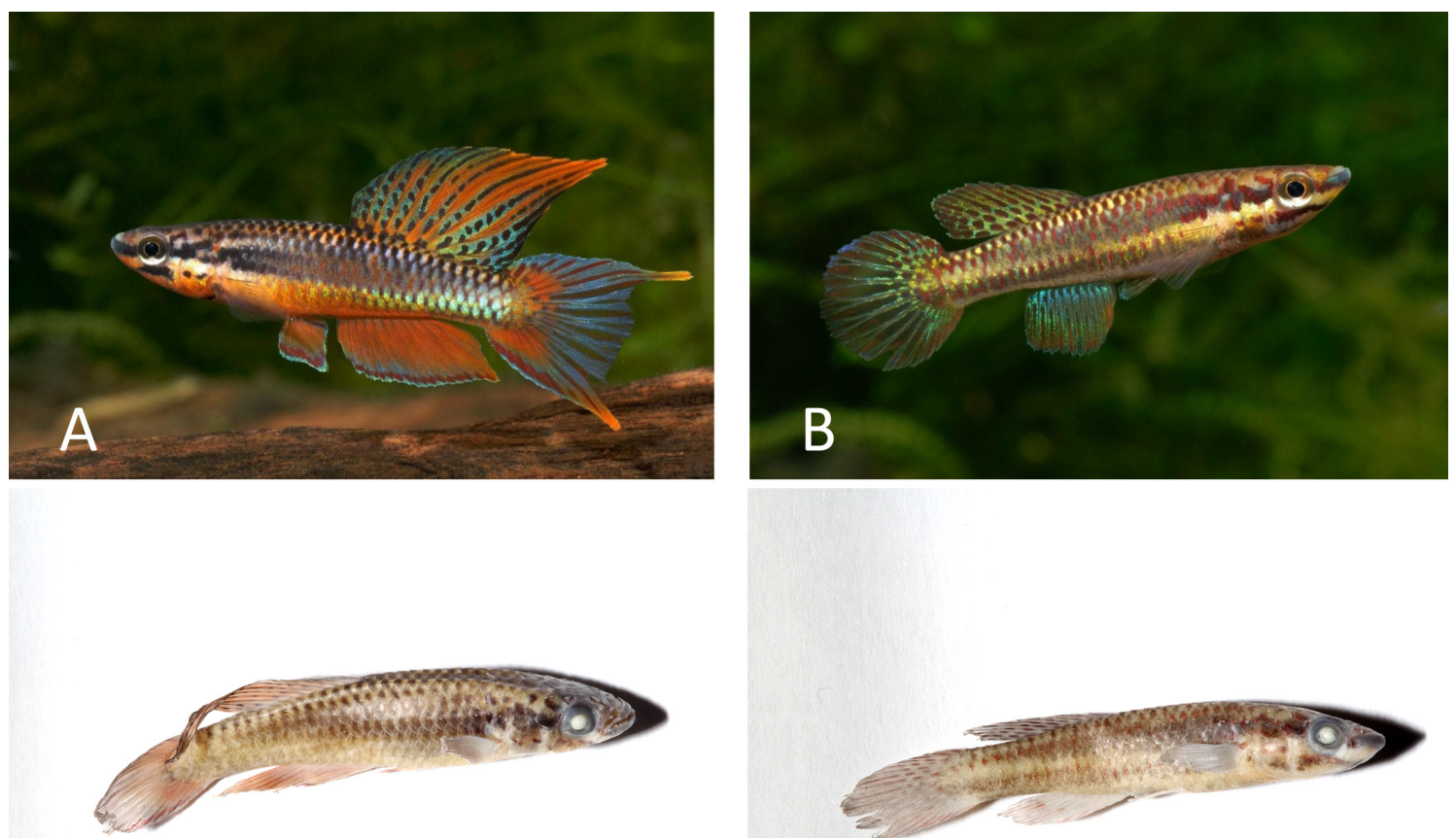

C
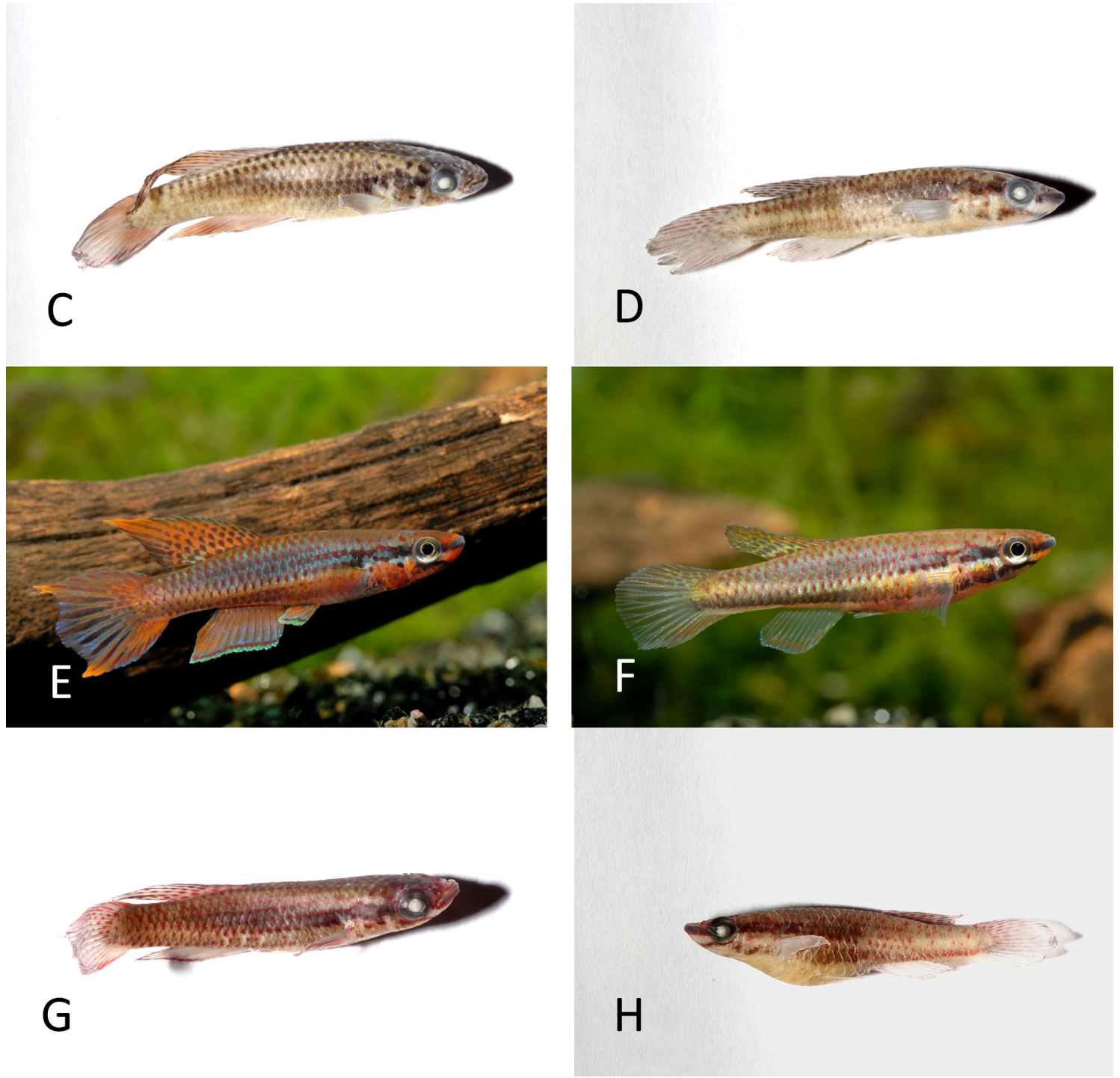

Fig. 6. A-D. Aphyosemion aurantiacum Chirio, Legros \& Agnèse sp. nov. A. Adult, đ̂, from locality 12, not preserved. Photo O. Buisson. B. Adult, $q$, from locality 12, not preserved. Photo O. Buisson. C. Holotype, adult, đ̂, from Wézé Spring (MRAC 2016-019-P-64). D. Paratype, adult, ๆ, from Wézé Spring (MRAC 2016-019-P-65-73). E-H. A. rubrogaster Chirio, Legros \& Agnèse sp. nov. E. Adult, §ิ, from locality 16, not preserved. Photo O. Buisson. F. Adult, $q$, from locality 16, not preserved. Photo O. Buisson. G. Holotype, adult, $\widehat{\jmath}$, from the Niengé River (MRAC 2016-019-P-93). H. Paratype, adult, , from the Niengé River (MRAC 2016-019-P-94-108). 
Table 7. Meristic and morphometric data of Aphyosemion aurantiacum Chirio, Legros \& Agnèse sp. nov. See Table 3 for the abbreviations used.

\begin{tabular}{ccccccc}
\hline Character & N & HT & Min & Max & Mean & SD \\
\hline D & 29 & 12 & 10 & 13 & 11.21 & 0.86 \\
A & 29 & 12 & 12 & 15 & 13.21 & 0.98 \\
D/A & 29 & 1 & -1 & 2 & 0.86 & 0.88 \\
L.L. & 29 & $26(+2)$ & $24(+1)$ & $27(+3)$ & $25.52(+1.86)$ & $0.83(+0.52)$ \\
pDor & 29 & 12 & 11 & 13 & 12.38 & 0.56 \\
TRAV & 29 & 8 & 7 & 8 & 7.1 & 0.31 \\
S.L. & 29 & 33 & 22.2 & 33 & 26.85 & 2.84 \\
T.L. (\%) & 29 & 120 & 112 & 135 & 122.92 & 5.22 \\
P.D. (\%) & 29 & 58 & 47 & 67 & 56.52 & 4.21 \\
P.A (\%) & 29 & 55 & 47 & 65 & 56.78 & 3.22 \\
P.V.(\%) & 29 & 45 & 39 & 51 & 46.31 & 2.69 \\
Ht (\%) & 29 & 21 & 16 & 21 & 18.15 & 1.46 \\
dcp (\%) & 29 & 13 & 9 & 14 & 11.57 & 1.2 \\
Hd (\%) & 29 & 30 & 22 & 33 & 29.33 & 2.29 \\
I.O. (\%) & 29 & 16 & 12 & 19 & 14.3 & 1.68 \\
Eye (\%) & 29 & 7 & 6 & 9 & 6.78 & 0.81 \\
\hline
\end{tabular}

\section{Paratypes}

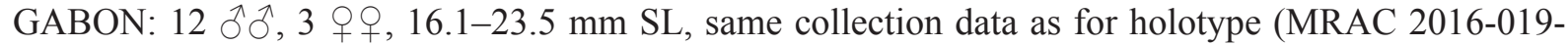
P-94-108); 13 §ิ đે, 18.9-26.6 mm SL, upper Alowé River, 0.70581 S, 9.47592 E, 48 m a.s.l., field reference code CHRSP6-Alowé, 4 Mar. 2016, Laurent Chirio leg. (MRAC 2016-019-P-109-121).

\section{Differential diagnosis}

Differs from all other species in A. alpha group through combination of following features: head with very intense reddish colour, flanks bluish-orange, ventral region orange (vs never same colour pattern). Distinguished from all other species of Chromaphyosemion by an alpha-shaped mark on pre- and postopercular region (vs no alpha-shaped mark, only some red macules).

\section{Colouration of live males (Fig. 6E)}

FLANKS AND VENTER. Flanks orange and bluish with two often visible dark lateral stripes, four lines of red dots from opercle to caudal peduncle. Ventral region orange, region between end of the anal fin and caudal peduncle is intense orange. Dorsal region brown and bluish, with two rows of paradorsal copper scales from the operculum to caudal peduncle with two lines of carmine red dots.

HEAD. Very intense red, premaxilla reddish, mandible reddish with black lower lips, reddish supraorbital region, reddish infraorbital region with black macule, postorbital region bluish-grey with black macule, orange pre-opercle with two black macules, orange opercle with one black macule; black macules on pre- and post-opercular regions, revealing alpha-shaped mark.

Fins. Dorsal fin orange, blue on posterobasal portion of fin, with rows of carmine red dots between rays, carmine red streaks on distal and posterobasal portions of fin. Orange acumen on apex. Anal fin orange, with blue zone near submarginal band, regular, red submarginal band, blue marginal band and 
orange acumen. No punctuation. Caudal fin blue, orange on upper and lower lobes, with some red dots on median region, very long red streaks on median region and in upper and lower lobes, irregular, red submarginal band, blue marginal band and orange acumens. Pelvic fins orange with no punctuation, blue zone near submarginal band, submarginal red band, blue marginal band. Pectoral fins with orange reflections.

\section{Colouration of live females (Fig. 6F)}

FLANKS AND VENTER. Flanks pale beige, four lines of red dots from opercle to caudal peduncle, two dark lateral stripes, venter pale beige, white on basal portion. Two rows of paradorsal brown scales in dorsal region from operculum to caudal peduncle with red dots.

HEAD. Premaxilla brown, mandible yellow-orange with black lower lips, with brown supraorbital region, white infraorbital region with black macule, white postorbital region with one black macule, pale blue pre-opercle, orange opercle with two macules.

Fins. Dorsal fin yellow-green, orange on distal portion, with rows of carmine red dots between rays. Anal fin translucent, orange zone on distal portion, blue on edge. Caudal fin translucent, orange on ventral portion of fin, red dots on dorsal portion of the fin near caudal peduncle. Pelvic fins translucent with orange reflection, blue reflection on edges. Pectoral fins translucent.

\section{Colouration of ethanol-preserved males and females (Fig. 6G-H)}

FLANKS AND VENTER. Flanks of males grey with four lines of red dots, venter whitish. Two rows of paradorsal red scales in grey dorsal region, the operculum to caudal peduncle, with two visible greyish lateral stripes. Flanks of females beige with two grey lateral stripes, four lines of red dots from opercle to caudal peduncle, incomplete near the peduncle; venter yellowish, with two grey lateral stripes. Two rows of paradorsal red scales in brown dorsal region, from operculum to caudal peduncle.

HeAD. Male with whitish mandible with black lower lips (Alowé specimens: orange below mandible), infraorbital region with one red macule, orange pre-opercular region and opercle region, and opercle with two small black macules. Head of female with black lower lips, infraorbital region with red macule, orange opercle.

Fins. Dorsal fin of male light orange with red dots and some red streaks on edge. Anal fin orange with red submarginal band. Caudal fin orange on median portion, with red streaks on upper portion, and red submarginal band. Dorsal fin of female whitish, rows of red dots between rays. Anal fin whitish, with no red dots. Caudal fin whitish, with some red dots on upper portion, red streaks on edge.

\section{Distribution and habitat}

This species has been found at two localities, one in the Niengé River (Table 1, Fig. 1) flowing towards Lake Gomé, itself flowing into the lower Ogooué River, and one in the Alowé River, flowing towards Lake Alombié, also flowing into the lower Ogooué River. The species has never been found elsewhere and seems to be endemic to this part of the lower Ogooué hydrographic basin. The habitat of this species differs quite significantly from that of the five other species: all specimens were found in 3 to 5 metre wide rivers with fast running water, and sandy bottoms with no aquatic vegetation. They were hidden in tree roots along the riverbanks, or under dead leaves at the mouth of small secondary brooks, but they were not found in the small brooks themselves. This species was found in syntopy with an undescribed species of Aphyosemion and an undescribed species of Plataplochilus. 
Table 8. Meristic and morphometric data of Aphyosemion rubrogaster Chirio, Legros \& Agnèse sp. nov. See Table 3 for the abbreviations used.

\begin{tabular}{ccccccc}
\hline Character & N & HT & Min & Max & Mean & SD \\
\hline D & 29 & 12 & 11 & 14 & 12,07 & 0.7 \\
A & 29 & 13 & 12 & 15 & 13.69 & 0.89 \\
D/A & 29 & 1 & 0 & 3 & 1.72 & 0.88 \\
L.L. & 29 & $27+1$ & $23(+1)$ & $27(+3)$ & $25.1(+1.83)$ & $1.08(+0.54)$ \\
pDor & 29 & 13 & 11 & 13 & 12.07 & 0.65 \\
TRAV & 29 & 8 & 6 & 8 & 7 & 0.38 \\
S.L. & 29 & 25.2 & 16.1 & 26.6 & 21.13 & 2.65 \\
T.L. (\%) & 29 & 124 & 111 & 130 & 120.68 & 4.47 \\
P.D. (\%) & 29 & 57 & 47 & 65 & 56.87 & 3.78 \\
P.A (\%) & 29 & 53 & 22 & 62 & 54.03 & 6.99 \\
P.V.(\%) & 29 & 44 & 39 & 52 & 45.75 & 2.98 \\
Ht (\%) & 29 & 12 & 12 & 42 & 17.64 & 4.92 \\
dcp (\%) & 29 & 17 & 9 & 17 & 11.31 & 1.58 \\
Hd (\%) & 29 & 27 & 15 & 34 & 28.62 & 3.49 \\
I.O. (\%) & 29 & 12 & 11 & 31 & 13.24 & 3.64 \\
Eye (\%) & 29 & 7 & 6 & 11 & 7.76 & 1.04 \\
\hline
\end{tabular}

\section{Identification key of the Aphyosemion alpha group species}

1. Anal fin without punctuation

- Anal fin with punctuation of black or red dots

2. Flanks orange and bluish, ventral region orange, very intense orange portion between the end of the anal fin and the caudal peduncle, head highly red-orange.

A. rubrogaster Chirio, Legros \& Agnèse sp. nov.

- Flanks beige, ventral region orange or beige, blue iridescent scales between the end of the anal fin and the caudal peduncle.

- Flanks blue or purplish blue, ventral region orange or bluish white, blue iridescent scales between the end of the anal fin and the caudal peduncle....

3. Anal fin with some red carmine macules, mauve on basal portion, orange on median portion, a yellowish portion near the submarginal band, red and regular submarginal band, blue marginal band, orange little acumen.

A. barakoniense Chirio, Legros \& Agnèse sp. nov.

- Anal fin blue with orange portion on basal region, without punctuation except black dots on basal and/or postero-basal portions, without submarginal and marginal bands. Some individuals may have some small black dots instead of the submarginal band.

A. flavocyaneum Chirio, Legros \& Agnèse sp. nov.

4. Two orange zones: orange portion on the opercle, venter beige with an orange portion above the pelvic fins, anal fin orange, blue near the basal portion and near the red submarginal band, dorsal fin orange, caudal fin blue with begin of upper and lower lobes light orange

A. pusillum Chirio, Legros \& Agnèse sp. nov.

- No delimited orange zone, opercle orange, ventral region entirely orange, anal fin orange with a blue zone upper the red submarginal band, dorsal fin blue with large orange zone on rays, caudal fin blue with an orange caudal peduncle A. aurantiacum Chirio, Legros \& Agnèse sp. nov. 
5. Dorsal fin brown-orange, greenish on basal portion, red dots between rays, little orange apex, caudal fin light blue, some red dots on basal region, very long red streaks on distal region, red and irregular submarginal band, blue marginal band, little acumens light orange, flanks blue, ventral region orange

A. alpha Huber, 1998

- Dorsal fin blue, orange distal portion near the apex, black dots between rays, very long orange acumen on the apex, caudal fin blue with orange portion on peduncle region, some red dots on basal region, very long red streaks on distal region, red and irregular submarginal band, blue marginal band, acumen orange very intense, flanks purplish blue, ventral region bluish white A. flammulatum Chirio, Legros \& Agnèse sp. nov.

\section{Discussion}

This high diversity present in the Wonga-Wongué Presidential Reserve is based on a single monophyletic group of species of the subgenus Chromaphyosemion. There are at least six different species in this small area $\left(4300 \mathrm{~km}^{2}\right.$, approximately $80 \mathrm{~km}$ north to south and west to east). This diversity may be underestimated, however, because three drainages (Liamé, Sangatanga and Ngélié) have not yet been investigated. The simplest hypothesis to explain this pattern is to consider that all these species originated from vicariance events. The Wonga-Wongué Presidential Reserve is composed of coastal hills, rising to $284 \mathrm{~m}$. These hills are ancient coastal dunes covered with a savannah and forest mosaic. Today, these hills separate rivers that were probably in contact with each other when the sea level was much lower. During the Pleistocene glaciation periods, the sea level dropped by more than 100 metres (Van Handel 1989). These level drops moved the coastline westward and allowed separate rivers to join and form new rivers or deltas. This has been demonstrated for example for the Seine and the Somme Rivers in France that joined in the English Channel during the cold periods (Antoine et al. 2000). The alternating cold and warm periods, corresponding to contact and separation periods for the rivers, may have generated multiple speciation events through accumulation of slight phenotypic differences (during isolation times) and reinforcement (during secondary contact) because of the ability of the female Chromaphyosemion to distinguish and preferentially mate with males of its own species and population (Kullmann \& Klemme 2007).

\section{Acknowledgements}

The authors would like to thank Nicolas Hubert for his help with the genetic analysis. This work was financed by the Institut des Sciences de l'Evolution de Montpellier (genetic study) (ISEM), the Institut de Recherche pour le Développement (IRD) and the Agence Nationale des Parcs Nationaux (ANPN). The latter allowed us to collect specimens from the Presidential Reserve of Wonga-Wongué. We also thank Flore Koumba Pambo from CENAREST for her help in obtaining the research permits. DNA sequences were produced through molecular genetic analysis in the technical facilities of the Centre Méditerranéen de l'Environnement et de la Biodiversité (CeMEB). We are grateful to Thibault Cavelier de Cuverville for his valuable help in collecting the fish and to Kate Abernethy for the corrections made to the last proofs of this text.

\section{References}

Agnèse J.-F., Zentz F., Legros O. \& Sellos D. 2006. Phylogenetic relationships and phylogeography of the killifish species of the subgenus Chromaphyosemion (Radda, 1971) in West Africa, inferred from mitochondrial DNA sequences. Molecular Phylogenetics and Evolution 40: 332-346. https://doi.org/10.1016/j.ympev.2006.03.018

Agnèse J.-F., Legros O., Cazaux B. \& Estivals G. 2013. Aphyosemion pamaense, a new killifish species (Cyprinodontiformes: Nothobranchiidae) from Cameroon. Zootaxa 3670 (4): 516-530.

https://doi.org/10.11646/zootaxa.3670.4.6 
Antoine P., Lautridou J.-P. \& Laurent M. 2000. Long-term fluvial archives in NW France: response of the Seine and Somme Rivers to tectonic movements, climatic variations and sea-level changes. Geomorphology 33: 183-207. https://doi.org/10.1016/S0169-555X(99)00122-1

Collier G. 2006. The genus Aphyosemion: taxonomic history and molecular phylogeny. Journal of the American Killifish Association 39 (5-6) : 147-168.

Felsenstein J. 1985. Confidence limits on phylogenies: an approach using the bootstrap. Evolution 39: 783-791. https://doi.org/10.2307/2408678

Huber J.H. 2000. Killi-Data 2000. Updated Checklist of taxonomic Names, collecting Localities and bibliographic References of oviparous Cyprinodont Fishes (Cyprinodontiformes); in French, English, German and Spanish. Société française d'Ichtyologie, Paris.

Huber J.H. 2006. Killi-Data Catalogue. Paris, France.

ICZN. 1999. International Code of Zoological Nomenclature. Fourth Edition. The International Trust for Zoological Nomenclature, London.

Kimura M. 1980. A simple model for estimating evolutionary rates of base substitutions through comparative studies of nucleotide sequences. Journal of Molecular Evolution 16: 111-120. https://doi.org/10.1007/bf01731581

Kullmann H. \& Klemme B. 2007. Female mating preference for own males on species and population level in Chromaphyosemion killifishes (Cyprinodontiformes, Nothobranchiidae). Zoology 110: 377386. https://doi.org/10.1016/j.zool.2007.08.001

Legros O., Zentz F. \& Agnèse J.-F. 2005. Description de deux nouveaux Chromaphyosemion (Teleostei: Aplocheilidae) du sud de la Plaine littorale camerounaise. Killi-Contact 33: 3-30.

Nei M., Kumar S. \& Takahashi K. 1998. The optimization principle in phylogenetic analysis tends to give incorrect topologies when the number of nucleotides or amino acids used is small. Proceedings of National Academy of Sciences 95: 12390-12397. https://doi.org/10.1073/pnas.95.21.12390

Saitou N. \& Nei M. 1987. The neighbor-joining method: a new method for reconstructing phylogenetic trees. Molecular Biology and Evolution 4: 406-425.

https://doi.org/10.1093/oxfordjournals.molbev.a040454

Sambrook J., Fritsch E.F. \& Maniatis T. 1989. Molecular Cloning: a Laboratory Manual. Cold Spring Harbor Laboratory Press, New York.

Scheel J.J. 1968. Rivulins of the Old World. TFH publications, New Jersey.

Scheel J.J. 1990. Atlas of Killifishes of the Old World. TFH publications, New Jersey.

Schwarz G. 1978. Estimating the dimension of a model. Annals of Statistics 6 (2): 461-464. https://doi.org/10.1214/aos/1176344136

Sonnenberg R. 2000. The distribution of Chromaphyosemion Radda, 1971 (Teleostei:Cyprinodontiformes) on the Coastal Plains of West and Central Africa. In: Rheinwald G. (ed.) Isolated Vertebrate Communities in the Tropics. Proceedings of the $4^{\text {th }}$ International Symposium, Bonn. Bonner zoologische Monographien 46: 79-94.

Sonnenberg R. 2007a. Two new species of Chromaphyosemion (Cyprinodontiformes: Nothobranchiidae) from the coastal plain of Equatorial Guinea. Ichthyological Exploration of Freshwaters 18: 359-373.

Sonnenberg R. 2007b. Description of three new species of the genus Chromaphyosemion Radda, 1971 (Cyprinodontiformes: Nothobranchiidae) from the coastal plains of Cameroon with a preliminary review of the Chromaphyosemion splendopleure complex. Zootaxa 1591: 1-38. 
Stamatakis A. 2014. RAxML Version 8: A tool for phylogenetic analysis and post-analysis of large phylogenies. Bioinformatics 30: 1312-1313. https://doi.org/10.1093/bioinformatics/btu033

Takahashi K. \& Nei M. 2000. Efficiencies of fast algorithms of phylogenetic inference under the criteria of maximum parsimony, minimum evolution, and maximum likelihood when a large number of sequences are used. Molecular Biology and Evolution 17: 1251-1258.

https://doi.org/10.1093/oxfordjournals.molbev.a026408

Tamura K. \& Nei M. 1993. Estimation of the number of nucleotide substitutions in the control region of mitochondrial DNA in humans and chimpanzees. Molecular Biology and Evolution 10 (3): 512-526. https://doi.org/10.1093/oxfordjournals.molbev.a040023

Tamura K., Peterson D., Peterson N., Stecher G., Nei M. \& Kumar S. 2011. MEGA5: Molecular Evolutionary Genetics Analysis using Maximum Likelihood, Evolutionary Distance, and Maximum Parsimony Methods. Molecular Biology and Evolution 28: 2731-2739.

https://doi.org/10.1093/molbev/msr121

UngV., Dubus G., Zaragüeta Bagils R. \& Vignes-Lebbe R. 2010. Xper2: introducing e-taxonomy. Bioinformatics 26 (5): 703-704. https://doi.org/10.1093/bioinformatics/btp715

Van Handel T.H. 1989. Late Quaternary sea-level changes and archaeology. Antiquity 63: 733-745.

Völker M.E. 2006. Karyotype Differentiation in Chromaphyosemion Killifishes (Cyprinodontiformes, Nothobranchiidae): Patterns, Mechanisms and Evolutionary Implications. PhD Thesis, University of Bonn, Germany.

Wildekamp R.H. 1993. A World of Killies. Atlas of the Oviparous Cyprinodontiform Fishes of the World. Volume 1. The American Killifish Association, Mishawaka, Indiana.

Zhang J., Kapli P., Pavlidis P. \& Stamatakis A. 2013. A general species delimitation method with applications to phylogenetic placements. Bioinformatics 29: 2869-2876.

https://doi.org/10.1093/bioinformatics/btt499

Manuscript received: 18 January 2018

Manuscript accepted: 18 June 2018

Published on: 30 October 2018

Topic editor: Rudy Jocqué

Desk editor: Kristiaan Hoedemakers

Printed versions of all papers are also deposited in the libraries of the institutes that are members of the EJT consortium: Muséum national d'Histoire naturelle, Paris, France; Botanic Garden Meise, Belgium; Royal Museum for Central Africa, Tervuren, Belgium; Natural History Museum, London, United Kingdom; Royal Belgian Institute of Natural Sciences, Brussels, Belgium; Natural History Museum of Denmark, Copenhagen, Denmark; Naturalis Biodiversity Center, Leiden, the Netherlands; Museo Nacional de Ciencias Naturales-CSIC, Madrid, Spain; Real Jardín Botánico de Madrid CSIC, Spain; Zoological Research Museum Alexander Koenig, Bonn, Germany. 